Review

\title{
Examining the Variables Leading to Apparent Incongruity between Antimethanogenic Potential of Tannins and Their Observed Effects in Ruminants-A Review
}

\author{
Supriya Verma ${ }^{1, *}$, Friedhelm Taube ${ }^{1,2}$ and Carsten S. Malisch ${ }^{1}$ (D) \\ 1 Grass and Forage Science/Organic Agriculture, Institute of Crop Science and Plant Breeding, \\ Christian-Albrechts-Universität zu Kiel, Hermann-Rodewald Str. 9, DE-24118 Kiel, Germany; \\ ftaube@gfo.uni-kiel.de (F.T.); cmalisch@gfo.uni-kiel.de (C.S.M.) \\ 2 Grass Based Dairy Systems, Animal Production Systems Group, Wageningen University (WUR), \\ 6708 PB Wageningen, The Netherlands \\ * Correspondence: sverma@gfo.uni-kiel.de; Tel.: +49-431-880-2137
}

Citation: Verma, S.; Taube, F.;

Malisch, C.S. Examining the Variables Leading to Apparent Incongruity between Antimethanogenic Potential of Tannins and Their Observed Effects in Ruminants-A Review. Sustainability 2021, 13, 2743.

https://doi.org/10.3390/su13052743

Academic Editor: Rajeev Bhat

Received: 5 January 2021

Accepted: 26 February 2021

Published: 3 March 2021

Publisher's Note: MDPI stays neutral with regard to jurisdictional claims in published maps and institutional affiliations.

Copyright: (c) 2021 by the authors. Licensee MDPI, Basel, Switzerland. This article is an open access article distributed under the terms and conditions of the Creative Commons Attribution (CC BY) license (https:/ / creativecommons.org/licenses/by/ $4.0 /)$.

\begin{abstract}
In recent years, several secondary plant metabolites have been identified that possess antimethanogenic properties. Tannin-rich forages have the potential to reduce methane emissions in ruminants while also increasing their nutrient use efficiency and promoting overall animal health. However, results have been highly inconclusive to date, with their antimethanogenic potential and effects on both animal performance and nutrition being highly variable even within a plant species. This variability is attributed to the structural characteristics of the tannins, many of which have been linked to an increased antimethanogenic potential. However, these characteristics are seldom considered in ruminant nutrition studies-often because the analytical techniques are inadequate to identify tannin structure and the focus is mostly on total tannin concentrations. Hence, in this article, we (i) review previous research that illustrate the variability of the antimethanogenic potential of forages; (ii) identify the source of inconsistencies behind these results; and (iii) discuss how these could be optimized to generate comparable and repeatable results. By adhering to this roadmap, we propose that there are clear links between plant metabolome and physiology and their antimethanogenic potential that can be established with the ultimate goal of improving the sustainable intensification of livestock.
\end{abstract}

Keywords: proanthocyanidins; condensed tannins; secondary plant metabolites; methane; ruminants; climate change

\section{Introduction}

Intensification and global expansion of livestock production systems have led to significant increased emissions of agricultural carbon dioxide $\left(\mathrm{CO}_{2}\right)$, nitrous oxide $\left(\mathrm{N}_{2} \mathrm{O}\right)$, and methane $\left(\mathrm{CH}_{4}\right)$, with agriculture contributing to almost $15 \%$ of the total anthropogenic greenhouse gas (GHG) emissions [1,2]. A major part of these emissions is in the form of $\mathrm{CH}_{4}(44 \%)$, while the rest is divided between $\mathrm{N}_{2} \mathrm{O}(29 \%)$ and $\mathrm{CO}_{2}(27 \%)$ (proportions expressed in terms of $\mathrm{CO}_{2}$-equivalent $\left(\mathrm{CO}_{2}\right.$-e) $)$. From 1990 to 2012 , global $\mathrm{CH}_{4}$ emissions have increased by $11 \%$ from 1869 million tonnes to 2080 million tonnes $\mathrm{CO}_{2}$-e. Methane has a shorter atmospheric lifespan (12 years) compared to $\mathrm{N}_{2} \mathrm{O}$ (114 years) and $\mathrm{CO}_{2}$ (up to thousands of years), and developing mitigation strategies for $\mathrm{CH}_{4}$ abatement will help reach the global GHG-reduction targets and temperature stabilization goals [2,3]. In addition to this potential for temperature stabilization, a reduction in $\mathrm{CH}_{4}$ emissions could further allow a reduction in existing atmospheric $\mathrm{CH}_{4}$, as the remaining $\mathrm{CH}_{4}$ emissions are naturally removed from the atmosphere within a short timespan [4-6]. Methane is released as a product of microbial degradation of feed macromolecules in the digestive tract of ruminants [7]. Ruminal methane emissions are the result of an inefficient pathway in ruminant digestion of feed and reducing these emissions would also be efficacious 
in preventing metabolizable energy losses; these comprise between 2 and $15 \%$ of the digestible energy intake depending on the forage quality [8-10]. Hence, the development and adoption of strategies and approaches to reduce $\mathrm{CH}_{4}$ emissions from livestock systems would have both environmental benefits and lead to improved feed utilization and animal productivity. Since $\mathrm{CH}_{4}$ production cannot be eliminated entirely without the ruminant losing its ability to digest fibre, the focus should be on increasing nutrient use efficiency in ruminant livestock [11].

One strategy with promising potential is the use of tannin-rich forages (TRFs). Tannins are polyphenolic plant secondary metabolites, which can precipitate or crosslink the proteins, thus making them less prone to proteolysis [12,13]. While several TRFs have been investigated for their antimethanogenic potential in numerous in vivo and in vitro trials, the results have so far been highly inconsistent. One such TRF is sainfoin (Onobrychis viciifolia). A study by Chung [14] indicated no difference between methane emissions from sainfoin and alfalfa hay in terms of dry matter intake (DMI), but identified $25 \%$ emission reductions from sainfoin based on the organic matter digested. In contrast, Huyen [15] showed that sainfoin silage diets decreased $\mathrm{CH}_{4}$ emissions (per unit DMI) by $5.8 \%$ compared to grass and maize silage. On the other hand, other studies reported increments in $\mathrm{CH}_{4}$ emissions when diets of sainfoin hay [16] and sainfoin silage [17] were fed. Similar discrepancies can be found in their effect on reducing bloat $[18,19]$ and shifting nitrogen $(\mathrm{N})$ excretion from urine to faeces $[14,15,20,21]$. These inconsistencies are still difficult to explain, although they may be partly explained by the lack of precise structural characterizations of tannins. Some studies have shown the intraspecies variation of tannin concentration and structures in sainfoin, indicating the complexity of tannin composition in forages [22,23], as well as the impact of the structures on antimethanogenic properties $[24,25]$. The co-presence of other secondary plant metabolites such as flavanols and saponins can also exert potential mutualistic or antagonistic effects $[10,26]$. Variations can also arise as a result of the growth conditions of the tested plants, which differed greatly across the reported experiments, and these can affect their secondary metabolite synthesis [27-30].

In this review, we (a) identify the potential of TRFs, specifically those containing condensed tannins (CTs, syn. proanthocyanidins), to affect rumen productivity and methanogenesis; (b) illustrate how the structural diversity within CTs is likely to contribute to explaining the inconsistencies observed; and (c) provide a roadmap to assess the bioactive potential of CT in livestock production systems. We aim to integrate the research on TRFs' potential to reduce methane emissions by understanding tannin synthesis, their mode of action in the animal and thereby, to indicate suitable analyses to improve their interpretability. If applied in practice, following this roadmap will increase the potential to extrapolate findings of antimethanogenic potential of forages.

\section{Understanding Tannins and Their Functional Attributes}

Previously, the sole function of tannins was regarded to be a part of a plant's defence mechanism against herbivory [13,31-33]. This trait conferred antiherbivory effects through (a) the ability of CT to precipitate proteins, thus rendering them unavailable for animal nutrition, and (b) they can have oxidative activities, which create oxidative stress in the herbivore gut [34].

In terms of their role in herbivore diets, plant tannins have surpassed their reputation of being purely antinutritional compounds and several of their beneficial functions have been identified. Tannins have been shown to possess the potential to reduce the impact of drought by acting as antioxidants and detoxifying reactive oxygen species produced as a result of drought stress [28,35]. Additionally, tannins and other polyphenols have been found to reduce the carbon and $\mathrm{N}$ mineralization rates in soil, by inhibiting the activity of soil microorganisms and enzymes [29,36]. At an individual plant level, this can result in long-term nutrient availability due to slower litter decomposition [29], while at the plant community level, this will enable better adaption of microorganisms to adapt to TRFs, thus 
generating a general "home field advantage" for one species [36], as well as increasing soil carbon stocks [37-40]. With the discovery of the additional functions of tannins, TRFs have emerged as a promising solution to help reduce $\mathrm{CH}_{4}$ emissions in ruminants, while concomitantly providing a series of additional environmental or animal health benefits. A selection of relevant properties will subsequently be discussed in more detail.

\subsection{What Are Tannins?}

Tannins are the end products of energy demanding and extensive biosynthetic pathways, indicating that they play an important role in plant metabolism. They can be broadly divided into two groups-hydrolysable tannins (HTs) and CTs-depending on their structure [31,41]. Hydrolysable tannins contain central polyol esterified with gallic acid molecules [12,42]. They can be further divided into three groups: simple gallic acid derivatives, gallotannins (GTs), and ellagitannins (ETs). The two first classes contain only galloyl groups attached to the central core (glucose/polyol): simple gallic acid derivatives having only monogalloyls groups, but GTs having digalloyl or even trigalloyl groups in series attached to the polyol. In ETs, two of the galloyls are C-C linked to make the characteristic hexahydroxydiphenoyl (HHDP) group that can be modified even further [12,42,43]. Condensed tannins are the second most abundant polyphenols after lignins, and consist of two or more flavan-3-ol monomeric units. The most common flavan-3-ol subunits of CTs are characterized based on the number of hydroxyl groups on the $\mathrm{A}$ and $\mathrm{B}$ rings, and the relative stereochemistry between the $\mathrm{B}$ and $\mathrm{C}$ rings (Figure 1).

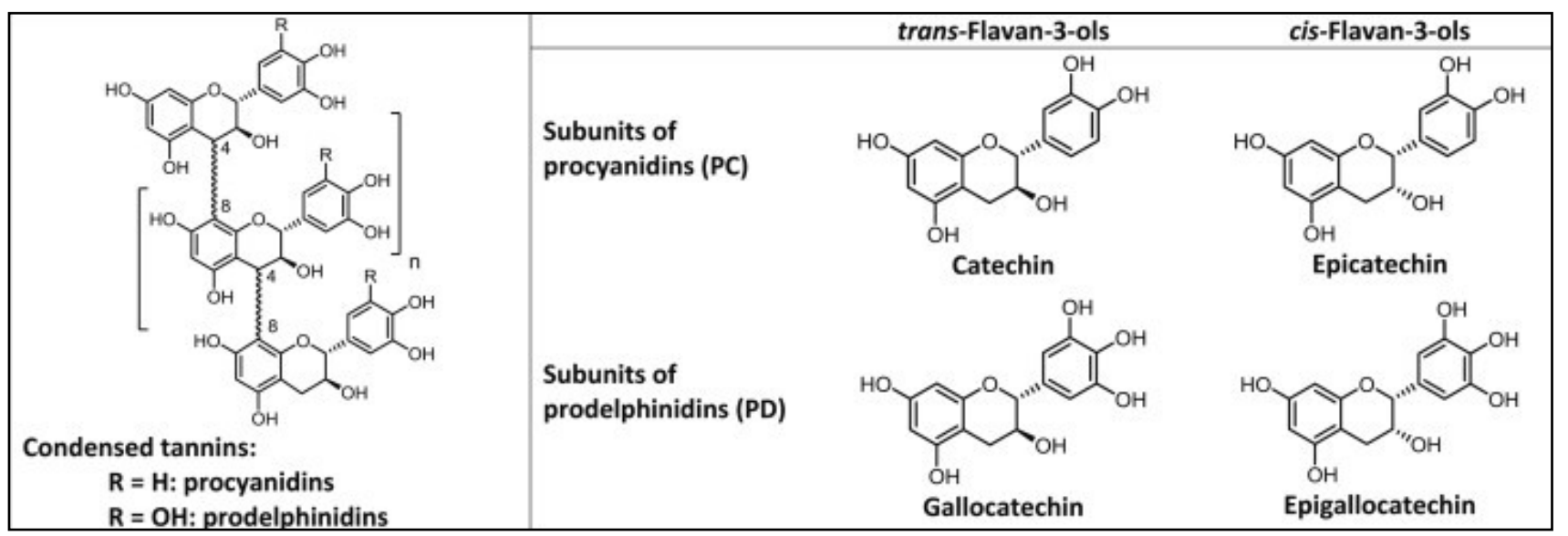

Figure 1. Structure of condensed tannin subunits [44].

Catechin and epicatechin have two hydroxyl groups present adjacent to each other on the B ring of flavon-3-ol subunits, and are categorized as procyanidin (PCs) units when found in CT structures. Gallocatechin and epigallocatechin have three hydroxyl groups adjacent to each other on the B ring and are categorized as prodelphinidin (PDs) units in CTs [33,45-47]. Additionally, both PCs and PDs can differ in their relative orientation of the C-2/C-3 carbon substituents of the C-ring, where catechin and gallocatechin have a transconfiguration, whereas epicatechin and epigallocatechin have a cis-configuration [48,49]. These subunits are connected through interflavan linkages, the most common of which are $B$ type linkages. In B type linkages, the bonds between the subunits are formed either between the $C-4$ carbon of the $C$ ring and the C-8 carbon of the subsequent flavan-3-ol subunit $(4 \rightarrow 8)$ or between the C-4 carbon and the C- 6 carbon $(4 \rightarrow 6)[50,51]$. When the covalent bond is formed between two flavon-3-ol subunits via a C-2 oxygen atom and a C-7 carbon in addition to the $4 \rightarrow 8 \mathrm{~B}$ linkage, the linkage is known as A type (Figure 2) [49]. 


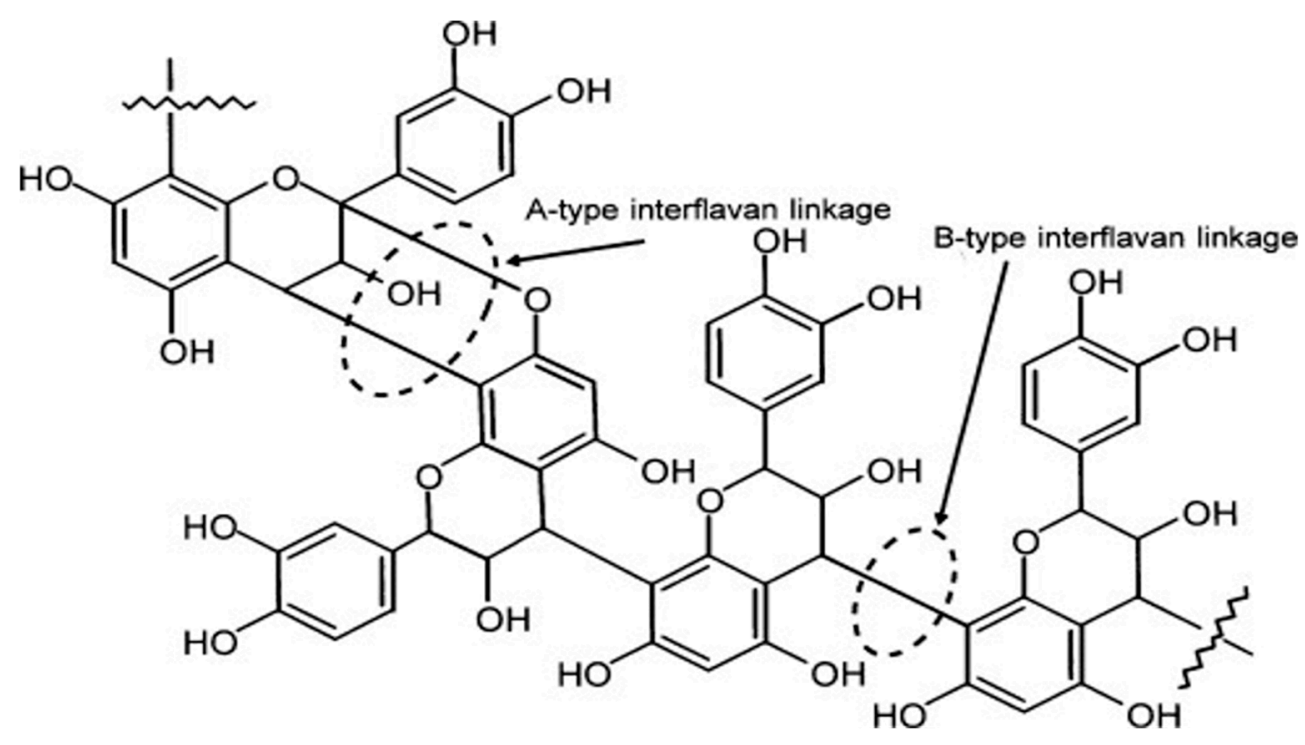

Figure 2. A- and B-type interflavan linkages in condensed tannin oligomers and polymers [52].

The proportions of PC and PD subunits, and also the type of linkages within CTs, vary substantially both across and within plant species $[53,54]$. These variations combined with the varying degrees of polymerization can lead to a multitude of combinations in structures and hence, a wide range of bioactive properties of CTs [55]

\subsection{Functional Attributes of Tannins}

The bioactive properties of tannins are either a result of their protein precipitation capacity (PPC), or their anti- or pro-oxidant behaviour. The effect of tannins on biological systems is found to be dependent on $\mathrm{pH}$, with protein precipitation capacity being generally efficient in slightly to moderately acidic environments, whereas the oxidative activity is expressed in alkaline environments or by oxidative plant enzymes, such as polyphenol oxidases [56].

The fate of ingested tannins in herbivores is dependent on the physiological conditions of their gut. Tannins when consumed by herbivores with high gut $\mathrm{pH}$, such as in caterpillars, undergo auto oxidation to produce semiquinone radicals and quinones. These oxidation products can bind to the nutrients in the gut lumen of the caterpillar and cause damage to the surrounding gut tissues [57]. In contrast, the effect of tannins on mammalian herbivores is dependent mainly on its PPC, as the mammalian gut has acidic to neutral gut conditions which provide an ideal environment for tannin-protein interactions [34]. When supplied in moderate quantities, the protein binding ability of tannins can improve nutrient utilisation in ruminants; however, in insects, both CTs and HTs had no impact on protein utilization $[58,59]$. Additionally, the efficacy of these effects is dependent on the structure of tannins. Ellagitannin-rich plants were found to be more potent in terms of their oxidative behaviour compared to plants rich in galloyl glucoses or CTs [57], and CTs are found to precipitate proteins more actively than ETs [33].

The anthelmintic and antimethanogenic bioactivity of CTs in ruminants is linked to their precipitation capacity $[60,61]$ and their antioxidative behaviour $[34,49,62]$. Condensed tannins are known to form insoluble complexes with proteins by binding to the protein's surface and forming a coat and this leads to its precipitation $[63,64]$. These complexes are generally based on non-covalent interactions such as hydrophobic interactions and hydrogen bonding [65]. However, there have been reports on ionic interactions and 
covalent bonds with amino acids or sulphur on proteins [66]. Additionally, under low $\mathrm{pH}$ and oxidative conditions, tannins can form covalent bonds with proteins $[38,65,67,68]$.

Independent of the bond type, within CTs, a higher PD percentage has been associated with a higher PPC, which is likely a result of the additional hydroxyl groups at carbon 5 of the B ring $[49,69,70]$. In addition to the PD/PC ratio, the cis/trans ratio, polymer size, and copresence of galloyl groups have been identified as having effects on the PPC [71]. However, these results have been inconsistent, which is likely a result of multiple structural features being responsible for the tannins' astringency concomitantly and potentially imparting contrasting effects $[59,72,73]$. The polyphenolic polarity, as defined by the octanol-water partition coefficient $\left(\mathrm{K}_{\mathrm{OW}}\right)$, can also influence the PPC of tannins [68]. Tannins with high $\mathrm{K}_{\mathrm{OW}}$ values (e.g., acacia (Acacia mearnsii) leaves, $\mathrm{K}_{\mathrm{OW}}=13.92$ ) are fat soluble and bind non-specifically to the proteins. They have the tendency to be adsorbed by animal tissues and exert toxic effects. Tannins with low $\mathrm{K}_{\mathrm{OW}}$ values such as chestnut (Castanea sativa) extracts $\left(\mathrm{K}_{\mathrm{OW}}=1\right)$ bind more efficiently with proteins and lead to better nutrient utilization in animals [59]. However, the nature of these interactions is also dependent on the proteins. For example, the PCs were found to have a stronger affinity for larger proteins with open structures such as BSA ( $66 \mathrm{kD}$ ) compared to lysozyme $(14.4 \mathrm{kD})$, which has a compact structure and is smaller in size $[50,59,66,68]$. Additionally, the isoelectric point ( $\mathrm{pI}$ ) of proteins has generally been identified to affect the tannins' protein precipitation behaviour [38], and proteins aggregate faster when the $\mathrm{pH}$ is close to their $\mathrm{pI}$ [68]. The reaction conditions also play a significant role in the strength of tannin-protein complexes. The variability in dietary composition with differences in protein chemistry (for example: proline content), amino acids, and CT composition, makes it exceptionally difficult to predict the response of CT-protein interactions. Finally, it should be mentioned that there appears to be at least a partial specificity, with plant tannins showing a higher precipitation of plant proteins, compared to animal protein. Accordingly, in a study by Zeller [51], tannins from birdsfoot trefoil (Lotus corniculatus) were better at precipitating proteins from lucerne (Medicago sativa), compared to BSA. Hence, the protein source should also be accounted for in the estimation of the PPC [74].

The link between PPC, oxidative properties, and the observed bioactivity of tannins is, however, still not clear because of the inadequate tests in many reported studies. Therefore, complementing their protein precipitation assays with the analysis of their anti-/prooxidative behaviour can provide a better overview and improve understanding of CTanimal interactions.

\subsection{Potential of Incorporating Tannin Rich Forages in Ruminant Nutrition}

As explained previously, tannins have long been considered to be non-specific antinutritive factors and potentially toxic, as they protect dietary protein from degradation, and because of their pro-oxidant properties [65]. These characteristics are undoubtedly true, as tannins have, indeed, been found to form strong, yet $\mathrm{pH}$-dependent and reversable bonds to proline rich proteins and affect protein digestibility [75]. Some browsing herbivores have developed the ability to produce proline-rich salivary mucoproteins as an evolutionary adaption to overcome the deleterious effects of tannins [66]. Herbivore palatability of TRFs is determined on the basis of astringency resulting from the interactions between CTs and the herbivore's salivary proteins. Tanniferous forages are often considered to be less palatable and therefore, less acceptable. At a CT concentration above $5 \%$ of the herbage dry matter (DM), intake and palatability of TRFs may be depressed and feed intake is reduced. However, reported results shows this is highly variable [49]. Despite its high CT concentration, sulla (Hedysarum coronarium) has been found to be highly acceptable by sheep [76]. Similarly, the acceptability (and assumed palatability) of sainfoin was found to be comparable to conventional temperate forages such as alfalfa and ryegrass/clover mixtures [77]. Sainfoin has also been reported to be more palatable than birdsfoot trefoil despite its higher tannin concentration $[77,78]$. 


\subsubsection{Impact of Tannins on Enteric Fermentation}

Feed constituents such as carbohydrates, proteins, and other organic polymers are degraded to their monomer components in the presence of rumen microbes under anaerobic conditions $[7,79,80]$. Tannin-rich forages have been reported to cause alterations in rumen microflora, increase nutrient utilization efficiency, improve animal health, and consequently, influence their environmental effect $[15,46,81,82]$. The presence of tannins in the feed has been found to slow down the degradation of the dietary proteins by forming tanninprotein complexes in the rumen [83]. These complexes are then transported from the rumen $(\mathrm{pH}=6-7)$ to the small intestine $(\mathrm{pH}>7)$, where they are partially dissociated under alkaline conditions. Through this process, the excess protein is initially protected from inefficient degradation in the rumen, so it reaches the small intestine as rumen bypass protein. As a result, there is an increased amino acids absorption throughout the entire digestive tract for tannin-containing feeds compared with non-tannin-containing feeds $[32,59,84]$. The decrease in excess protein degradation in the rumen also results in a decrease in methanogenesis and consequently, lower $\mathrm{CH}_{4}$ emissions. Concomitantly, the non-ammonia $\mathrm{N}$ transported to the small intestine leads to a higher production of milk, meat, and wool. This deviation further decreases the urinary $\mathrm{N}$ and slightly increases faecal $\mathrm{N}[10,59,78,85,86]$. The decrease in urinary $\mathrm{N}$ can lead to lower indirect $\mathrm{N}$ losses to the environment from the urine patches, as these spatially concentrated excretions have a high risk of volatilization, nitrification, and denitrification (Figure 3) [15,87].

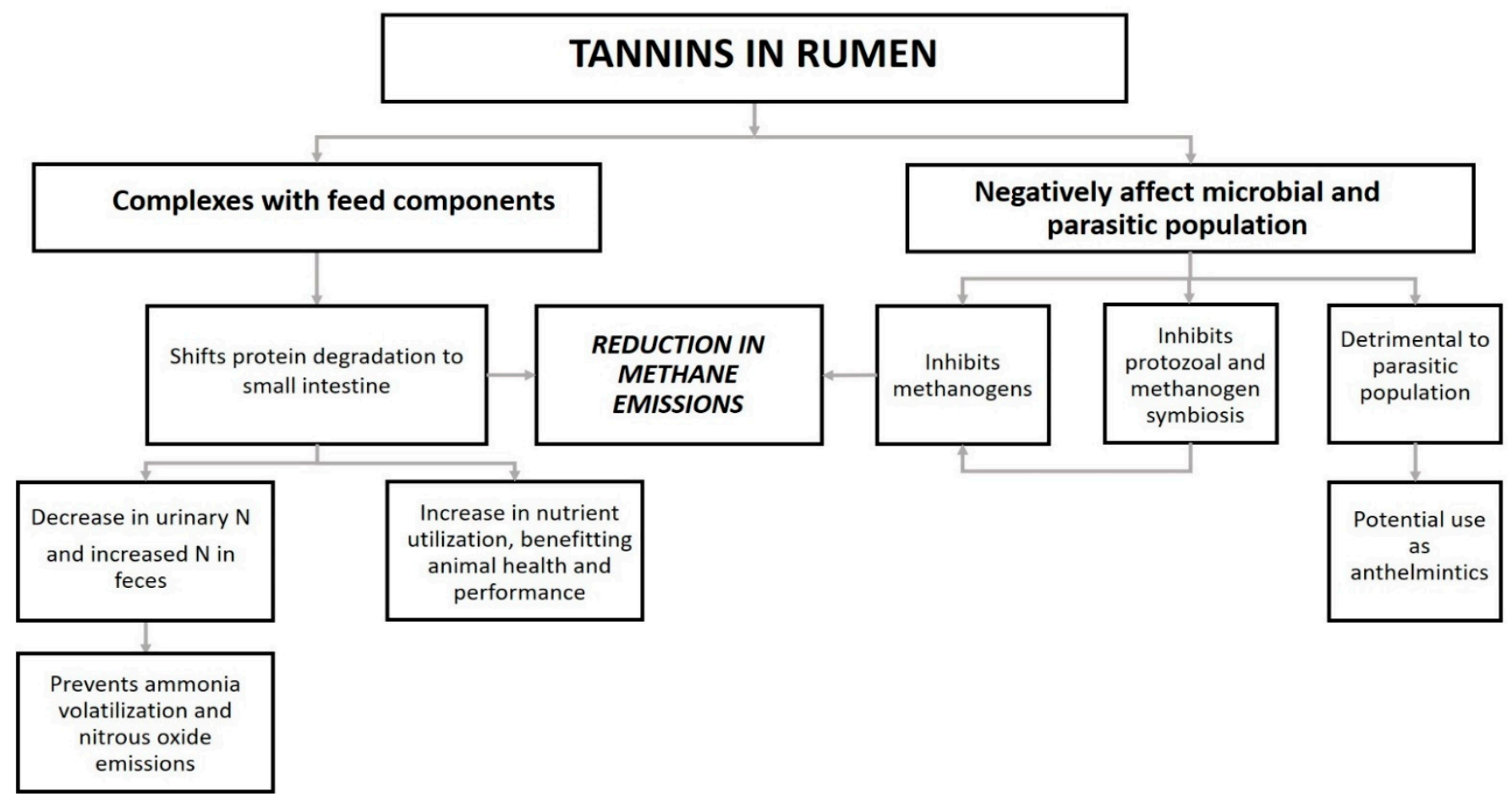

Figure 3. Beneficial effects of tannins on ruminant nutrition.

In temperate forage systems, the forage-protein concentrations in are generally higher than in tropical forages. Hence, the $\mathrm{N}$ use efficiency in temperate forages is often low, and in some instances, as low as around $10-20 \%[78,88]$. Accordingly, reductions in available protein can be achieved without adversely affecting milk yields by increasing the $\mathrm{N}$ use efficiency, thereby concomitantly reducing the nitrogen emissions to the environment. However, the effects of tannins in the gastrointestinal tract of ruminants are complex. For example, CTs in birdsfoot trefoil have a strong effect on the proteolytic bacteria in the rumen of sheep. As a result, plant protein degradation in the rumen is decreased and non-ammonia $\mathrm{N}$ flow to the small intestine is increased, resulting in higher utilizable crude 
protein $(\mathrm{uCP})$ in the small intestine $[89,90]$. However, even within the Lotus genus, big trefoil (Lotus pedunculatus) and birdsfoot trefoil have different modes of action in their effect on nitrogen flows. A direct comparison of these species shows that CTs from big trefoil were more effective in the degradation of Rubisco compared to those of birdsfoot trefoil. Similarly, CTs from big trefoil were able to inhibit the degradation of protein in the rumen by forming strong tannin-protein complexes, whereas birdsfoot trefoil tannins reduced degradation of proteins by directly inhibiting the proteases [91]. Additionally, big trefoil was found to have a stronger potential to reduce $\mathrm{CH}_{4}$ emissions than birdsfoot trefoil [59].

As a result of this complexity, in vivo experimentation has not yet been able to successfully show both a reduction in $\mathrm{CH}_{4}$ emissions and incremental improvement in $\mathrm{N}$ use efficiency simultaneously from tannin-containing forages. To illustrate the existing research gaps, it is important to understand how tannins influence rumen microbiota, as well as the interactions between hydrogen producers (bacteria, protozoa, fungi) and consumers (methanogens) [92].

\subsubsection{Mode of Action to Lower Methane Emissions}

Several mechanisms have been hypothesized by which tannins might decrease $\mathrm{CH}_{4}$ emissions in ruminants. Efficient nutrient utilization is considered to be one of the most likely explanations, and this might increase animal productivity and reduce $\mathrm{CH}_{4}$ production per unit of animal product. The inclusion of tannins in feed has been found to improve nutrient utilization in the ruminants, thereby reducing metabolic energy losses that would otherwise occur through $\mathrm{CH}_{4}$ emissions [79,93,94].

Another factor which could be linked to CT's potential in reducing $\mathrm{CH}_{4}$ emissions is its affinity to form complexes with lignocellulose and preventing fibre degradation, thereby leading to lower microbial fermentation [95]. Microbial fermentation leads to the formation of volatile fatty acids (VFA) such as acetate, propionate, and butyrate, with $\mathrm{CO}_{2}$ and $\mathrm{H}_{2}$. These metabolic byproducts are either absorbed by the rumen wall and used as a source of energy for animals or used as substrates by microorganisms $[7,79,94,96]$. Tannins have been known to reduce the $\mathrm{CH}_{4}$ emissions of ruminants either by directly inhibiting the ruminal methanogenic population [92,97], or by hindering the methanogenprotozoa symbiosis [49]. Approximately $37 \%$ of the $\mathrm{CH}_{4}$ from the ruminants is produced by protozoa-associated methanogens. In the methanogen-protozoa symbiosis, hydrogen $\left(\mathrm{H}_{2}\right)$ required by methanogens to produce $\mathrm{CH}_{4}$ is provided by rumen protozoal population via transfer of $\mathrm{H}_{2}$ produced in their hydrogenosomes. The subsequent utilization of $\mathrm{H}_{2}$ by methanogens benefits the protozoal population as $\mathrm{H}_{2}$ hinders their metabolism [10,98]. As the accumulation of $\mathrm{H}_{2}$ in the rumen can impede fermentation, methanogens play an important role in feed digestibility by utilizing the rumen borne $\mathrm{H}_{2}$. Hence, before adapting feeding strategies to achieve defaunation of the rumen, it is important to provide alternative $\mathrm{H}_{2}$ sinks to maintain the animal's productivity and improve the utilization of metabolizable energy from the feed $[99,100]$.

Here, tannins might be part of the solution as well, as some studies have hypothesized that tannins influence the VFA profile in rumen. They promote the shift towards the production of more propionate compared to acetate, which acts as a hydrogen sink. The reduced availability of $\mathrm{H}_{2}$, which is the main substrate for $\mathrm{CH}_{4}$ production, results in a reduction in methanogenesis $[86,100,101]$. The shift in acetate and propionate production could be attributed to changes in the composition of microbial communities and their activity [95]. However, the mechanism by which tannins influence methanogenesis and shift the VFA profile is still not well understood.

\section{Current Findings on the Antimethanogenic Potential of TRFs}

Recent studies have shown that the effect of tannins on ruminant nutrition is highly dependent on the tannin type, structural characteristics, dosage supplied, rumen morphology, and rumen physiology [102,103]. Numerous plant species containing tannins have been studied to determine their efficacy in ruminant nutrition, either as forages or feed 
additives. These species include acacia, quebracho (Schinopsis balansae), chestnut, valonea (Quercus Aegilops), leucaena (Leucaena leucocephala), desmodium (Desmodium ovalifolium), sainfoin, birdsfoot trefoil, big trefoil, Chinese bushclover (Lespedeza cuneata), Japanese clover (Lespedeza striata), white clover (Trifolium repens), and sulla [59,86,101].

Antimethanogenic potential was found to vary across the species. Promising temperate forage species include sainfoin, birdsfoot trefoil, big trefoil, and sulla, and among tropical forages are leucaena, desmodium, and Chinese bushclover [24,62,104,105]. A study of Friesian dairy cows found that cows that grazed on birdsfoot trefoil produced not only $17.5 \%$ less $\mathrm{CH}_{4}$ emissions (per unit DMI) but also $32 \%$ less $\mathrm{CH}_{4}$ emissions $/ \mathrm{kg}$ milk solids when compared with cows grazing on perennial ryegrass (Lolium perenne) [106]. Similarly, leucaena, a tropical leguminous shrub, has been found to reduce $\mathrm{CH}_{4}$ emissions in sheep and heifers without affecting DMI or organic matter intake in the animals $[107,108]$. In another study, when supplied with $80 \%$ leucaena in the diet compared with a basal diet of Pennisetum purpureum, $\mathrm{CH}_{4}$ emissions were reduced by $61 \%$ in heifers without negatively affecting DMI and VFA production [109]. The overall performance of the lambs (approx. 6 months age) was improved when CTs were included in their basal diet (wheat straw, oat hay, and concentrate mixture). Condensed tannins in the diet were supplied as leaf meal mixture of Ficus infectoria and Psidium guajava (70:30). The diet with $2 \%$ CTs was able to suppress $\mathrm{CH}_{4}$ emissions by approx. $26 \%$. Additionally, improved $\mathrm{N}$ metabolism, wool yield, and growth performance of lambs was reported. Inclusion of CTs in the feed did not affect the intake or apparent palatability of the feed [110].

Similarly, in a study conducted on adult sheep, hazel (Corylus avellana) leaves when supplemented at $50 \%$ of the total diet were able to reduce $\mathrm{CH}_{4}$ emissions by $35 \%$ (per unit OM intake) compared to the control (ryegrass hay and lucerne pellets). Concomitantly, a substantial decrease in urinary $\mathrm{N}$ proportion of total $\mathrm{N}$ intake was observed without any negative effects on forage intake, apparent palatability, or body weight of the sheep [111]. However, despite the promising findings indicated by these studies, the antimethanogenic potential of the forages is not clearly linked to the tannin concentration, as evidenced by the high variability in results from different studies (Table 1). As summarized in Table 1, the variation in $\mathrm{CH}_{4}$ abatement by forages also depends on the phenological stage at which they are harvested and by the method of forage preservation. In addition to the changes in forage chemical composition, phenological stage also affects the CT composition and structural features. The bioactivity of sainfoin CTs was found to decrease with maturity, as shown by the increase in phenological stage. This could be attributed to the lower proportion of extractable CTs (ECTs) resulting from increase in CT polymerization with maturity [112]. Similarly, when TRFs are ensiled, the process can rupture plant cells, allowing the CTs to release and bind to other molecules. This decreases the proportion of free CTs (ECTs) and hence, there is reduced bioactivity of CTs in conserved forages compared to fresh forages in terms of their ability to reduce $\mathrm{CH}_{4}$ emissions [21].

Furthermore, the mode of action by which these forages reduce $\mathrm{CH}_{4}$ emissions remains largely unclear. Tannins from chestnut, quebracho [113], and leucaena [114,115] have been found to reduce $\mathrm{CH}_{4}$ by reducing different methanogenic populations in the rumen. There was a significant effect of high molecular weight $\left(\mathrm{M}_{\mathrm{W}}\right) \mathrm{CT}$ fractions from Leucaena on richness and species diversity of rumen methanogenic and bacterial population in rumen. The study showed that $C$ Ts with high $\mathrm{M}_{\mathrm{W}}$ had a pronounced inhibitory effect on proteolytic bacteria, Prevotella spp., and Methanobrevibacter population [97,116]. 
Table 1. A short overview of methane production potential of tropical and temperate forages.

\begin{tabular}{|c|c|c|c|c|c|c|c|c|}
\hline $\begin{array}{c}\text { Plant } \\
\text { Species }\end{array}$ & Age & Fraction & Preservation & $\underset{(\%)}{\mathrm{ECT}}{ }^{*}$ & $\begin{array}{c}\text { Animal } \\
\text { (Rumen Fluid) }\end{array}$ & $\begin{array}{c}\text { Methane } \\
\text { (g/kg DM) }\end{array}$ & $\begin{array}{c}\text { Study } \\
\text { (Duration) }\end{array}$ & Reference \\
\hline $\begin{array}{l}\text { Acacia. } \\
\text { angustissima } \\
\text { var hirta } \\
\text { (STX) }\end{array}$ & Mature & Leaves & Fresh & 4.9 & Steers & 0.6 & In vitro $(48 \mathrm{~h})$ & {$[90,117]$} \\
\hline $\begin{array}{c}\text { Acacia } \\
\text { angustissima } \\
\text { var. hirta } \\
\text { (STP5) }\end{array}$ & Mature & Leaves & Fresh & 4.4 & Steers & 0.8 & In vitro (48 h) & {$[90,117]$} \\
\hline $\begin{array}{c}\text { Desmanthus } \\
\text { illinoensis } \\
\text { (Michx.) } \\
\text { MacMill }\end{array}$ & Mature & Leaves & Fresh & 5.1 & Steers & 24.9 & In vitro (48 h) & {$[90,117]$} \\
\hline $\begin{array}{l}\text { Desmodium } \\
\text { paniculatum } \\
\text { var. } \\
\text { paniculatum }\end{array}$ & Mature & Leaves & Fresh & 10.3 & Steers & 7.9 & In vitro (48 h) & {$[90,117]$} \\
\hline $\begin{array}{l}\text { Lespedeza } \\
\text { cuneata }\end{array}$ & Mature & Leaves & Fresh & 4.7 & Steers & 15.1 & In vitro (48 h) & {$[90,117]$} \\
\hline $\begin{array}{c}\text { Lespedeza } \\
\text { stuevei }\end{array}$ & Mature & Leaves & Fresh & 9.9 & Steers & 4.9 & In vitro (48 h) & {$[90,117]$} \\
\hline $\begin{array}{l}\text { Leucaena } \\
\text { retusa }\end{array}$ & Mature & Leaves & Fresh & 2.4 & Steers & 40.7 & In vitro (48 h) & {$[90,117]$} \\
\hline $\begin{array}{c}\text { Mimosa } \\
\text { strigillosa }\end{array}$ & Mature & Leaves & Fresh & 9.9 & Steers & 7.6 & In vitro (48 h) & {$[90,117]$} \\
\hline Neptunia lutea & Mature & Leaves & Fresh & 7.0 & Steers & 19.7 & In vitro $(48 \mathrm{~h})$ & {$[90,117]$} \\
\hline $\begin{array}{l}\text { Onobrychis } \\
\text { viciifolia acc } \\
\text { LRC } 3519\end{array}$ & Early stage & Herbage & Fresh & 2.5 & Cross bred heifers & 28.2 & In vivo (24 h) & [14] \\
\hline $\begin{array}{c}\text { Onobrychis } \\
\text { viciifolia acc } \\
\text { LRC } 3519\end{array}$ & Late stage & Herbage & Fresh & 0.7 & Cross bred heifers & 24 & In vivo (24 h) & [14] \\
\hline $\begin{array}{c}\text { Onobrychis } \\
\text { viciifolia acc } \\
\text { LRC } 3519\end{array}$ & Mature & Herbage & Hay & 0.6 & Cross bred heifers & 22.5 & In vivo (24 h) & [14] \\
\hline $\begin{array}{l}\text { Medicago } \\
\text { sativa }\end{array}$ & Early stage & Herbage & Fresh & 0 & Cross bred heifers & 26.6 & In vivo (24 h) & [14] \\
\hline $\begin{array}{l}\text { Onobrychis } \\
\text { viciifolia cv. } \\
\text { Perly }\end{array}$ & Mature & Herbage & Silage & 3.7 & $\begin{array}{l}\text { Brown Swiss } \\
\text { cows }\end{array}$ & 18.75 & In vitro (24 h) & [17] \\
\hline $\begin{array}{l}\text { Onobrychis } \\
\text { viciifolia cv. } \\
\text { Shoshone }{ }^{1}\end{array}$ & $\begin{array}{c}\text { Early } \\
\text { Flowering }\end{array}$ & Herbage & Hay & 3.9 & $\begin{array}{l}\text { Holstein dairy } \\
\text { cows }\end{array}$ & 12.9 & In vitro $(24 \mathrm{~h})$ & [118] \\
\hline $\begin{array}{c}\text { Lotus } \\
\text { corniculatus } \\
\text { cv. Norcen }{ }^{1}\end{array}$ & $\begin{array}{c}\text { Early } \\
\text { Flowering }\end{array}$ & Herbage & Hay & 0.4 & $\begin{array}{l}\text { Holstein dairy } \\
\text { cows }\end{array}$ & 11.7 & In vitro (24 h) & [118] \\
\hline $\begin{array}{c}\text { Lotus } \\
\text { corniculatus } \\
\text { cv. Ober- } \\
\text { haunstadter } \\
1\end{array}$ & $\begin{array}{c}\text { Early } \\
\text { Flowering }\end{array}$ & Herbage & Hay & 0.7 & $\begin{array}{l}\text { Holstein dairy } \\
\text { cows }\end{array}$ & 11.8 & In vitro (24 h) & [118] \\
\hline $\begin{array}{c}\text { Lotus } \\
\text { corniculatus } \\
\text { cv. Bull }\end{array}$ & Mature & Herbage & Silage & 2.2 & $\begin{array}{l}\text { Brown Swiss } \\
\text { cows }\end{array}$ & 17.64 & In vivo (24 h) & [17] \\
\hline $\begin{array}{c}\text { Lotus } \\
\text { corniculatus } \\
\text { cv. Polom }\end{array}$ & Mature & Herbage & Silage & 0.8 & $\begin{array}{l}\text { Brown Swiss } \\
\text { cows }\end{array}$ & 18.75 & In vivo (24 h) & [17] \\
\hline $\begin{array}{c}\text { Lotus } \\
\text { corniculatus }\end{array}$ & Vegetative & Herbage & Silage & 2.5 & $\begin{array}{l}\text { Friesian dairy } \\
\text { cows }\end{array}$ & 26.9 & In vivo $(24 \mathrm{~h})$ & [119] \\
\hline $\begin{array}{l}\text { Lolium } \\
\text { perenne }\end{array}$ & Mature & Herbage & Fresh & 0 & $\begin{array}{l}\text { Friesian dairy } \\
\text { cows }\end{array}$ & 24.15 & In vivo (24 h) & [106] \\
\hline $\begin{array}{c}\text { Lotus } \\
\text { corniculatus }\end{array}$ & Mature & Herbage & Fresh & 0.2 & $\begin{array}{c}\text { Friesian dairy } \\
\text { cows }\end{array}$ & 19.9 & In vivo (24 h) & [106] \\
\hline $\begin{array}{c}\text { Lotus } \\
\text { pedunculatus }\end{array}$ & Mature & Herbage & Fresh & 8 & Sheep & 14.5 & In vivo $(24 \mathrm{~h})$ & [119] \\
\hline $\begin{array}{l}\text { Hedysarum } \\
\text { coronarium }\end{array}$ & Mature & Herbage & Fresh & 2.8 & $\begin{array}{c}\text { Friesian and } \\
\text { Jersey dairy cows }\end{array}$ & 19.5 & In vivo $(24 \mathrm{~h})$ & [120] \\
\hline
\end{tabular}

\footnotetext{
${ }^{1}$ Refers to feed supplied in total mixed ration, ${ }^{*}$ Extractable condensed tannins.
} 
Similarly, birdsfoot trefoil and sainfoin were found to inhibit the proteolytic bacterial population [49]. A study analysing the effect of different tannin sources on $\mathrm{CH}_{4}$ emissions found that CT-rich (acacia and quebracho tannins) and HT-rich (chestnut and valonea tannins) affect rumen fermentation differently. At concentrations above $5 \% \mathrm{DM}$, in addition to a significant decrease in $\mathrm{CH}_{4}$ emissions, there was also a negative effect on total VFA production. CT-rich extracts reduced the acetate/propionate ratio significantly at a concentration higher than $5 \%$. However, the ratio was not affected by HT extracts, indicating that they had a stronger impact on methanogen population in comparison with substrate fermentation. Only valonea extracts $(5 \% w / w)$ were able to reduce $\mathrm{CH}_{4}$ emissions without any negative impact on fermentation and VFA profile. This indicates that classification based solely on tannin concentration or the type of tannins (HTs and CTs) present in the feed is not sufficient to determine their potential to reduce $\mathrm{CH}_{4}$ emissions [86]. Similarly, a study was performed on CT-rich forages from Texas to determine the effect of different functional features (PPC and antioxidative activity) on $\mathrm{CH}_{4}$ emissions. No effect of PPC was found on $\mathrm{CH}_{4}$ abatement, whereas the correlation between antioxidative property of tannins and decrease in $\mathrm{CH}_{4}$ emissions was significant. In contrast to previous studies, the decrease in acetate/propionate in this study was not correlated with a decrease in $\mathrm{CH}_{4}$ emissions [90]. The results from these studies further reinforce the need for CT structural characterization in addition to concentration, in order to make an accurate assessment of their impact on ruminant nutrition.

\section{Existing Research Gaps and Future Directions}

As discussed in the previous sections, several studies have tried to explore the properties that affect tannin astringency. However, the variations in the results obtained, and their lack of reproducibility, hinder their field-scale applicability. Furthermore, their structural complexity and the varied forage chemical composition among different species present difficulties for understanding the implications that CTs have for ruminant nutrition and particularly their antimethanogenic potential. Although several studies have identified a large variability in both the concentration and structure of CTs across species and their cultivars $[22,32,74]$, few studies have analysed the implications of this variability on the observed bioactivity. In the following sections, we present a brief overview about the factors responsible for current situation, with an apparent incongruity regarding the influence of tannins on ruminant nutrition. We also discuss the frequently used analytical techniques for qualitative and quantitative analysis of tannins and the underlying problems associated with them. Our aim here is to illustrate the importance of optimized tannin analyses and inclusion of tannin structural features in animal studies to overcome inconsistent animal responses. By avoiding these factors, which cause substantial variation in the reported studies, we can focus more precisely on CT-animal interactions.

\subsection{Experimental and Analytical Incongruities}

Tannin concentration and composition in plant has been reported to be substantially influenced by changes in environmental conditions, as well as by plant species and its phenological stage [40]. The preparation and handling of tannin extracts can also cause alterations in quantification of tannins [121]. In order to ensure accurate determination of tannin concentration and composition in a plant tissue, handling and storage protocols should be followed, as CT concentration is highly influenced by the environmental factors. Quantitative analyses are essential for determining CT bioavailability in the samples and spectrophotometric assays are routinely utilized due to their rapid and low-cost analysis. Due to their structural complexity, the number of derivatisation and analytical techniques are few and they have certain limitations. Substantial information about the activity of CTs can be obtained by analysing specific structural traits of tannins as it is difficult to isolate individual large polymeric CT units compared to dimers or trimers [122]. The complexity of CT structures means that they are frequently analysed by a method where multiple techniques with different functions are integrated together. 


\subsubsection{Growth Conditions of Experimental Plants}

Tannin concentrations in plants can be up to $20 \%$ of their total dry weight [38]. Although, CTs are found in different parts of the plant and they are predominantly concentrated in young leaves and flowers $[105,123]$. The concentration of tannins in tropical plants is, on average, higher than in temperate plants, yet there is substantial variation across seasons and environmental factors [62]. Drought, nutrient availability, and other conditions during plant growth have also been shown to affect CT concentration and composition. Although the effect of these abiotic stresses on the CT composition has not been well researched $[27,28,124]$, they have been shown to produce incremental effects in CT concentrations $[84,125]$. Accordingly, it was observed that the concentration of CTs in sulla was higher in the summer than in spring [54]. Similarly, Quercus rubica had higher tannin concentration and less polymerized tannins when grown in dry conditions compared with wet conditions [62]. Thus, it is important to account for and report the precise experimental conditions because of their potential to affect the observed tannin concentration, composition, and bioactivity [126].

\subsubsection{Sample Preservation and Storage}

After harvest, sample preservation plays an important role in the quantification of $\mathrm{CTs}$, as their extraction and quantification are heavily influenced by biotic factors. For precise tannin concentration and composition analysis, samples should be freeze-dried, rather than air or oven dried. In a direct comparison, hay-drying of samples from purple prairie clover (Dalea purpurea Vent.) resulted in a slight decrease in ECTs from 70.2 to $64.1 \mathrm{~g} \mathrm{~kg} \mathrm{DM}^{-1}$, while the protein-bound CTs increased from 9.0 to $12.4 \mathrm{~g} \mathrm{~kg} \mathrm{DM}^{-1}$. With ensiled samples, the differences were even more pronounced, and in these samples, ECTs decreased to $27.4 \mathrm{~g} \mathrm{~kg} \mathrm{DM}^{-1}$, while protein-bound CTs increased their concentration to $44.3 \mathrm{~g} \mathrm{~kg} \mathrm{DM}^{-1}$ [127]. Thus, while the total CT concentration did not differ, without freeze drying at least a part of the CTs, it can change from the available form to the protein-bound form, which is often not accounted for in the studies analysing bioactivity of tannins. Similarly, when comparing different drying methods for the concentration of HTs in white birch (Betula pubescens), oven drying reduced the ET concentration significantly from 10.9 to $8.4 \mathrm{~g} \mathrm{~kg} \mathrm{DM}^{-1}$, while simultaneously increasing the concentration of insoluble ET from 0.8 to $2.4 \mathrm{~g} \mathrm{~kg} \mathrm{DM}^{-1}$. In this study, neither storing the samples at $-20^{\circ} \mathrm{C}$ for 3 months prior to drying nor vacuum or air drying resulted in a decrease in ellagitannins or total HTs despite a minor but non-significant decrease in air dried samples [121]. This indicates that the adverse effect from air and oven drying increases with the air temperature, yet the short-term effect at room temperature appears to be negligible. The effect of temperature during post drying storage is less clear, and storage at $25^{\circ} \mathrm{C}$ for three weeks reduced tannins in walnuts by $20-40 \%$ (dependent on the subsequent extraction technique), with large parts of the reduction having occurred in the first week [128]. However, with regard to the HTs from birch, a one-year storage period at room temperature $\left(22^{\circ} \mathrm{C}\right)$ yielded lower tannin concentrations compared to samples that were stored in a freezer, with 17.4 and $19.1 \mathrm{~g} \mathrm{~kg} \mathrm{DM}^{-1}$, respectively. This value was still higher than the HT concentration in the samples stored in a refrigerator at $4{ }^{\circ} \mathrm{C}$, which yielded $15.7 \mathrm{~g} \mathrm{~kg} \mathrm{DM}^{-1}$ [121]. Contrasting results were obtained by Kardel [129], where samples stored in a refrigerator for one year had on average $3.5 \%$ higher CT concentrations than samples stored at room temperature. In this study, also storing the samples in an oven at $60^{\circ} \mathrm{C}$ for 5 days had no measurable impact on CT concentrations.

\subsubsection{Tannin Extraction}

While the vast majority of studies use aqueous acetone to extract tannins of any kind, with either 70 or $80 \%$ acetone, there is no clear indication about the superiority of any extraction method yet. Some studies have also used methanol or hot water extraction as well. Accordingly, the extraction yields with hot water were $6 \%$ higher on average, compared to a water/methanol (1:1) extraction solvent, and 13\% higher compared to 
an acetone/water/formic acid (70:29.5:0.5) solvent [129]. This study only determined the tannin concentration and did not evaluate potential changes in the structure due to the high temperatures. Contrary to these findings, Salminen [121] found that aqueous acetone extraction yielded on average $41 \%$ more extractable HT, compared to aqueous methanol extraction, although the study did not test hot water extraction. Pure acetone, however, yielded the lowest HT concentrations, with a reduction of almost $75 \%$ compared to acetone/water (70:30). The extraction yield of the 70\% acetone was increased even further by $29 \%$, if ascorbic acid was added to the acetone water mixture, presumably because it prevented oxidation of the HTs [121]. This is in accordance with the findings of Chavan [130] and Hagerman [131] for CTs, where 70\% acetone also provided the highest extraction yields compared to all methanol mixtures and acetone mixtures with higher acetone concentrations. Acidification of aqueous acetone extraction solvent with $1 \mathrm{~mL}$ of concentrated $\mathrm{HCl}$ further increased the extraction yields by around $10 \%$.

Some recent studies have, however, indicated in general much lower performance from maceration-based techniques compared to techniques such as ultrasonic baths, microwave-assisted extraction (MAE), and Soxhlet extraction. Aspé [132] identified much larger cell wall destruction from these last three techniques, which resulted in generally much higher extraction yields compared to maceration techniques, where only minor cell wall damage has occurred. According to Chupin, et al. [133], MAE effectiveness depends on the particle size and increases with small particles. However, they generally did not identify an effect of MAE on the structure of the tannins.

In addition to the solvent, the extraction conditions can also affect the efficiency of extraction. Extraction at $4{ }^{\circ} \mathrm{C}$ in darkness led to around $14-17 \%$ higher recovery of CTs compared to extraction at room temperature, also in dark conditions [134].

\subsubsection{Major Analytical Techniques I: Spectrophotometric Assays}

Spectrophotometric assays are routinely used in studies due to their rapid and lowcost analysis. Vanillin and HCl-butanol assays are conventionally employed to quantify CTs. Both these assays have been widely used in the majority of studies due to their accessibility and low cost for quantifying CTs. In principle, results from the HCl-butanol assay are more reproducible than the vanillin assay. Vanillin assay with methanol has been found to lack specificity as in addition to CTs, it complexes with flavan-3-ols and dihydrochalcones [84,135]. In the HCl-butanol assay, CTs are depolymerized oxidatively to form bright coloured anthocyanidins in the presence of mineral acids [135]. The HCl- butanol assay in some instances lacks specificity and leads to over- or underestimation of results as the colour is dependent on the interflavonoid linkages and 5-OH groups [126]. For accurate quantification by the HCl-butanol assay, freeze-dried samples should be preferred as under heat treatment, tannins can bind to other macromolecules which could undergo oxidation. Macromolecules containing phenolic groups can be oxidised to form quinones which can lead to condensation reactions between tannins and other macromolecules, thereby preventing the release of anthocyanidins from the modified tannins [84]. Furthermore, the addition of iron increases the specificity of this assay [135]. The addition of acetone to the assay also leads to the complete dissociation of CTs from the plant material and this inclusion has further refined this method [136]. A wide range of studies use tannic acid, catechin, or leucocyanidin as standards for these assays. This is also one of the sources for which there is a huge variation in the results, as seen in Table $2[84,129]$. 
Table 2. Variability of condensed tannins concentration in frequently studied species across different studies.

\begin{tabular}{cccc}
\hline Species & Condensed Tannins (\% DM) & Coefficient of Variation (\%) & References \\
\hline Acacia angustissima & $7.4-8.9$ & 9.3 & {$[117,137]$} \\
Acacia nilotica & $0.46-8$ & 67.4 & {$[137-140]$} \\
Acacia senegal & $0.07-7.8$ & 138.9 & {$[137,139]$} \\
Acacia tortilis & $4.7-5.4$ & 9.8 & {$[137,139]$} \\
Lespedeza cuneata & $0.83-5.1$ & 36.2 & {$[117]$} \\
Leucaena leucocephala & $0.52-18$ & 112.7 & {$[109]$} \\
Mimosa caesalpinifolia & $1.8-12.4$ & 105.5 & {$[117,141]$} \\
Hedysarium coronarium & $0.4-3.8$ & 68.1 & {$[76,142,143]$} \\
Onobrychis viciifolia & $2.4-14.1$ & 113.1 & {$[14,18,78,144]$} \\
Lotus corniculatus & $1.4-7.6$ & 45.3 & {$[78,106,145-148]$} \\
Lotus pedunculatus & $0.25-0.8$ & 50.9 & {$[119,147,149]$} \\
Onobrychis viciifolia (Silage) & $2.6-3.7$ & 17.4 & {$[17,21]$} \\
Lotus corniculatus (Silage) & $2.2-3.4$ & 22.3 & {$[17,119]$} \\
\hline
\end{tabular}

4.1.5. Major Analytical Techniques II: Liquid Chromatography Coupled with Mass Spectrometry

High-Performance Liquid Chromatography (HPLC) has been proven to be a competent and rapid method for the analysis of polyphenols apart from the highly polymerized oligomers [48,150]. Reverse phase LC (RPLC) is a commonly used chromatographical technique to analyse CTs, ranging from monomers to tetramers and in some cases, their isomers distinctly [151]. With increased CT polymerization, the intelligibility of the chromatogram in RPLC decreases due to the presence of unresolved peaks. The combination of fluorescence detection with RPLC leads to increases in selectivity and sensitivity of the method [152]. A UV-DAD detector is most frequently complemented with LC for the determination of CTs. It also helps in the direct classification of polyphenols into different subgroups such as flavonoids, ellagitannins, gallic acid derivatives, and caffeic acid derivatives, etc. [153]. Recently, to increase the specificity and resolution of the LC analysis, separation techniques have been coupled with ESI-MS or matrix-assisted laser desorption/ionization time-of-flight (MALDI-TOF) MS [154]. These are used extensively for the analysis of CTs in plant and food material such as cocoa, grapes, wine, and birch species, etc. $[155,156]$. Soft ionization methods such as ESI or MALDI are used to ionize non-volatile analytes such as biopolymers and detect highly polymerized CTs. MALDI-MS has identified procyanidins of degree of polymerization (DP) of 15 in unripe apples, for seed coats of soyabeans until DP of 30 [157]. Similarly, the combination of Hydrophilic Interaction Chromatography (HILIC) x RPLC with fluorescence detection and electrospray full scan mass spectrometry (ESI-MS) resulted in high resolution analysis. This method was able to detect procyanidins with DP value of 16 and gallolylation degree of 8 in the grape seed extracts [158]. These methods are constantly evolving and are now able to provide rapid quantitative and qualitative results. One such method is the Engstrom method which utilizes ultra-high performance liquid chromatography (UPLC) separation coupled with DAD and negative ion ESI-MS to generate a polyphenolic profile directly from plant extracts. In addition to the quantification of different polyphenolic groups, it provides an insight into the composition of flavonols, CTs, HTs, and structural features of condensed tannins $[159,160]$. These methods provide a great deal of information on tannin structural diversity, but due to high operational costs, their use is not yet widespread.

\subsection{Influence of CT Structural Features on Ruminant Nutrition Is Still Ambiguous}

The additive influence of CT structural features on the antimethanogenic potential of CT forages remains largely unexplored. Although research on CT structure and functional features has progressed immensely $[64,158,160]$, only a small number of studies have assessed their impact on $\mathrm{CH}_{4}$ abatement. These studies have shown that CT composition, and the concentration of CTs present in forages, are both significant determinants of their 
antimethanogenic potential $[24,90,95,161]$. One of the major reasons is that CTs exist as highly polymerized structures, so large polymers cannot be easily purified as individual compounds and are studied in terms of certain structural features such as molecular weight, polymer size, and prodelphinidin proportion [33]. High structural variability across and within the species adds to the difficulty for assessing their structure-activity relationship. This has been shown in studies on sainfoin cultivars where antimethanogenic potential was found to be highly variable. Hatew [24] studied the intraspecies variability by analysing 46 different accessions of sainfoin with CT concentrations ranging from 0.6 to $2.8 \%$ of DM for their antimethanogenic potential. Emissions were analysed based on CT structural properties, i.e., $\mathrm{mDP}$ (12 to 84 ), percentage of trans isomers (12 to $34 \%$ ), and PD (52.7 to $94.8 \%$ ) in CT. These properties have been associated with the astringency of CTs. It was observed that PD percentage was a primary $\mathrm{CT}$ structural characteristic responsible for reducing $\mathrm{CH}_{4}$ emissions in this in vitro study [24]. Weight-average $\mathrm{M}_{\mathrm{W}}$ of CTs was shown to have little impact on reduction in $\mathrm{CH}_{4}$ production $\left(\mathrm{R}^{2}=0.0009\right)$ from North American native forage plants [117]. Nevertheless, it is important to note that the variation in $\mathrm{CH}_{4}$ reduction potential of different species also arises from plant morphology, CT interaction with feed components, and the presence of other plant secondary metabolites $[162,163]$. The impact of CT structural features was found to be more pronounced in the studies conducted on CT extracts from plants. The additive effect of other secondary metabolites and forage quality parameters could be voided by the addition of purified CT extracts in the feed. Studies have shown that inclusion of CT extracts (40 mg/g DM) from leucaena (hybrid-Bahru) and mangosteen (Garcinia mangostana L) peel could reduce $\mathrm{CH}_{4}$ emissions by 45 and 35 percent, respectively. In both studies, Panicum maximum substrate was used as control. The inhibitory effect of mangosteen peel extracts $\left(\mathrm{M}_{\mathrm{w}}=2081\right)$ was milder than leucaena $\left(\mathrm{M}_{\mathrm{W}}=2737\right)$ owing to its lower $\mathrm{M}_{\mathrm{W}}$ but it was associated with fewer negative effects on in vitro DM degradability and lower protein binding affinity $[164,165]$. When the antimethanogenic potential of leucaena extracts with differing average molecular weights was tested, extracts with the highest $\mathrm{M}_{\mathrm{W}}$ were able engender $\mathrm{CH}_{4}$ to the maximum $[161,166]$. Table 3 summarizes the data from two different in vitro studies where at the same concentration, the effect of the molecular weight was more pronounced and it had a strong negative correlation with $\mathrm{CH}_{4}$ emissions.

Table 3. Influence of molecular weight on methane emissions from two in vitro studies using Kedah-Kelantan cattle rumen fluid.

\begin{tabular}{|c|c|c|c|c|c|}
\hline Extracts & $\begin{array}{l}\mathrm{CT}^{1} \\
(\%)\end{array}$ & $\begin{array}{c}\mathrm{M}_{\mathrm{W}}^{2} \\
(\mathrm{Da})\end{array}$ & $\begin{array}{c}\text { Total Gas } \\
\left(\mathrm{mL} \mathrm{g}^{-1} \mathrm{DM}\right)\end{array}$ & $\begin{array}{c}\text { Methane } \\
\left.\text { (mL } g^{-1} \mathrm{DM}\right)\end{array}$ & Reference \\
\hline Leucaena leucocephala hybrid-Rendang & 3 & 1265.8 & 57 & 8.07 & [161] \\
\hline Leucaena leucocephala hybrid-Rendang & 3 & 1028.6 & 61.6 & 9.2 & {$[161]$} \\
\hline Leucaena leucocephala hybrid-Rendang & 3 & 652.2 & 67 & 9.35 & [161] \\
\hline Leucaena leucocephala hybrid-Rendang & 3 & 562.2 & 67.3 & 10.27 & [161] \\
\hline Leucaena leucocephala hybrid-Rendang & 3 & 469.6 & 69.7 & 11.06 & [161] \\
\hline Leucaena leucocephala hybrid-Bahru & 3 & 1348 & 49.8 & 4.6 & [166] \\
\hline Leucaena leucocephala hybrid-Bahru & 3 & 857 & 51.8 & 5.6 & [166] \\
\hline Leucaena leucocephala hybrid-Bahru & 3 & 730 & 56 & 7.8 & [166] \\
\hline Leucaena leucocephala hybrid-Bahru & 3 & 726 & 55.5 & 9.7 & [166] \\
\hline Leucaena leucocephala hybrid-Bahru & 3 & 494 & 57.5 & 9.5 & [166] \\
\hline \multicolumn{5}{|c|}{ Correlation between molecular weight and methane production } & -0.72 \\
\hline
\end{tabular}

${ }^{1} \mathrm{CT}$ : Condensed tannins, ${ }^{2} \mathrm{M}_{\mathrm{W}}$ : Molecular weight of condensed tannins.

Some studies have also analysed the impact of multiple structural features simultaneously from CT extracts. Extracts from multiple sainfoin cultivars and diverse CT sources were analysed for CT structural features such as PD percentage, cis flavan-3-ols percentage, and average polymer size (mean degree of polymerization). PD percentage and average polymer size were found play an important role in determining antimethanogenic 
potential of CTs, in addition to the actual CT concentration $[25,95]$. This shows that high reproducibility of the results can be attained by incorporating the structural features of CTs in ruminant nutrition studies.

\subsection{A Roadmap to Close the Missing Links and Possible Future Directions}

As discussed above, there is an apparent incongruity between measured tannin concentrations and their bioactive effects. This may be explained by a combination of four factors: (a) the variability of tannins and their composition is large both within and amongst species, and it is affected, at least partially, by the environment; (b) most studies have used too few plants and have been conducted under non-controlled environmental conditions or not comparable conditions, to capture the variability of the tannins; (c) many studies have used inadequate or unsuitable analytical techniques (often due to lack of alternatives or resources), which do not capture the structural characteristics; and (d) the studies that investigated the antimethanogenic potential of CTs while accounting for structural attributes are still limited.

To overcome these inconsistencies, in future studies, every aspect that might affect the results, from the growing conditions to growth stage of the plant at harvest, and from sampling to extraction should be carefully considered in future studies. In the absence of laboratory infrastructure for the structural characterisation of CTs, assays to determine their astringency could be employed. Protein precipitation and radial diffusion assays are frequently used to measure the protein binding ability of tannins [167-169]. Furthermore, assays that determine their antioxidative and oxidative (at high $\mathrm{pH}$ ) behaviour could also be utilized. They have been associated with the negative impact of tannins on the rumen microbial population [90] and their antiherbivore effect [33], respectively. Additional treatments with polyethylene and polyvinylpolypyrrolidone in vitro studies could be employed to elucidate the tannin effect on $\mathrm{CH}_{4}$ emissions, as they bind specifically to tannins. These studies could be instrumental in distinguishing between the effect of tannins and forage chemical composition on $\mathrm{CH}_{4}$ emissions. In vitro fermentation $/ \mathrm{CH}_{4}$ production techniques could be useful for screening these forages and determining their adequate supplementation. Using CT extracts of tanniferous forages in in vitro studies can illustrate the structure-activity relationship of CTs with methane emissions more distinctly. Condensed tannin supplementation has been found to impact the diversity and composition of the rumen microbial community [170]. Understanding the dynamics of microbial populations in rumen, and how CT-containing forages influence their abundance and diversity, can provide significant insights into their mode of action. Employing novel techniques such as metagenome and metatranscriptome analysis of the rumen microbiome under CT treatment can help in identifying the microbial population and the functional shifts in rumen microbiome which lead to $\mathrm{CH}_{4}$ abatement [171]. As we gather more information about the relationship between the structure of CTs and their bioactivity, there are prospects for breeding plants with desired concentrations and composition of CTs $[105,172]$. Molecular approaches have already made it possible for white clover to reach moderate levels of CT in its leaves [173] and efforts are also being made in directions to improve the persistence of TRFs, as may be seen for birdsfoot trefoil [174]. Several questions still remain unanswered, and these are critical for ensuring a comprehensive understanding of the fate of CTs in biological systems.

- How do different environmental conditions influence the structural features of CTs?

- To what extent are the structural features responsible for the functional attributes of tannins (PPC and oxidative property) and whether these assays could be utilized as an indicator of their antimethanogenic activity?

- How does the presence of other secondary plant metabolites affect the influence of tannins on $\mathrm{CH}_{4}$ emissions?

- How does tannin supplementation affect mineral and vitamin bioavailability in ruminants? Which properties are primarily responsible for these interactions? 
- How do forage conservation methods (ensiling vs. hay drying vs. fresh material) influence the palatability/acceptability and DMI by livestock, and anthelmintic and antimethanogenic potential of TRFs?

- To what extent are the anthelmintic effects of tannins sustained during long-term trials? Is it possible for gastrointestinal parasites to develop resistance to tannins?

- How do the PPC and oxidative capacity of tannins influence their antimethanogenic potential? What is the magnitude of their effect on antimethanogenic potential?

- How do different tannin sources influence rumen microbiome diversity and abundance and whether these effects are short or long term?

- How do CTs interact with feed constituents and how do structural characteristics play a role in this?

\title{
5. Conclusions
}

In recent years, there have been remarkable new insights into CT structural diversity and functions with more sensitive analytical methods. However, CT bioactivity is a complex process which results from a multitude of variations occurring simultaneously in plants as well as in their effects in animals. The variability in the results from different studies focuses our attention on the need for developing and adapting a course of action for the investigation of potential of CTs to reduce $\mathrm{CH}_{4}$ emissions. The comparison of $\mathrm{CT}$ fingerprints of different species could help us understand not only the factors which define their antimethanogenic potential but also provide a vital framework to assess their interactions with plant constituents and rumen microflora, benefitting overall ruminant health.

\begin{abstract}
Author Contributions: S.V. and C.S.M. conceived and conceptualized the manuscript. S.V. took the lead for writing the manuscript, while C.S.M. and F.T. edited for clarity and completeness. All authors provided critical feedback and helped shape the research, analysis and manuscript. Additionally, all authors have read and agreed to the published version of the manuscript. All authors have read and agreed to the published version of the manuscript.
\end{abstract}

Funding: This research was funded by Deutsche Forschungsgemeinschaft (DFG)—Project number 406534244, grant number MA 8199'/1-1. We acknowledge financial support by DFG within the funding programme Open Access Publizieren.

Institutional Review Board Statement: Not applicable.

Informed Consent Statement: Not applicable.

Data Availability Statement: Not applicable.

Acknowledgments: The authors would like to thank Juha-Pekka Salminen for his contributions to improve the quality of this manuscript.

Conflicts of Interest: The authors declare no conflict of interest.

\section{References}

1. Haque, M.N. Dietary manipulation: A sustainable way to mitigate methane emissions from ruminants. J. Anim. Sci. Technol. 2018, 60, 1-10. [CrossRef] [PubMed]

2. Gerber, P.J.; Steinfeld, H.; Henderson, B.; Mottet, A.; Opio, C.; Dijkman, J.; Falcucci, A.; Tempio, G. Tackling Climate Change Through Livestock: A Global Assessment of Emissions and Mitigation Opportunities; Food and Agriculture Organization of the United Nations (FAO): Rome, Italy, 2013.

3. Ehhalt, D.; Prather, M.; Dentener, F.; Derwent, R.; Dlugokencky, E.J.; Holland, E.; Isaksen, I.; Katima, J.; Kirchhoff, V.; Matson, P. Atmospheric Chemistry and Greenhouse Gases; Pacific Northwest National Lab. (PNNL): Richland, WA, USA, 2001.

4. Allen, M.R.; Shine, K.P.; Fuglestvedt, J.S.; Millar, R.J.; Cain, M.; Frame, D.J.; Macey, A.H. A solution to the misrepresentations of $\mathrm{CO}_{2}$-equivalent emissions of short-lived climate pollutants under ambitious mitigation. NPJ Clim. Atmos. 2018, 1, 1-8. [CrossRef]

5. Broucek, J. Production of methane emissions from ruminant husbandry: A review. J. Environ. Prot. 2014, 5, 1482-1493. [CrossRef]

6. Lauder, A.R.; Enting, I.G.; Carter, J.O.; Clisby, N.; Cowie, A.L.; Henry, B.K.; Raupach, M.R. Offsetting methane emissions-An alternative to emission equivalence metrics. Int. J. Greenh. Gas. Control. 2013, 12, 419-429. [CrossRef]

7. Ellis, J.L.; Dijkstra, J.; Kebreab, E.; Bannink, A.; Odongo, N.E.; McBride, B.W.; France, J. Aspects of rumen microbiology central to mechanistic modelling of methane production in cattle. J. Agric. Sci. 2008, 146, 213-233. [CrossRef] 
8. Flachowsky, G.; Lebzien, P. Effects of phytogenic substances on rumen fermentation and methane emissions: A proposal for a research process. Anim. Feed Sci. Technol. 2012, 176, 70-77. [CrossRef]

9. Jayanegara, A.; Wina, E.; Takahashi, J. Meta-analysis on methane mitigating properties of saponin-rich sources in the rumen: Influence of addition levels and plant sources. Asian Australas. J. Anim. Sci. 2014, 27, 1426-1435. [CrossRef]

10. Jayanegara, A.; Goel, G.; Makkar, H.P.S.; Becker, K. Reduction in Methane Emissions from Ruminants by Plant Secondary Metabolites: Effects of Polyphenols and Saponins; Food and Agriculture Organization of the United Nations (FAO): Rome, Italy, $2010 ;$ pp. 151-157. ISBN 978-92-5-106697-3.

11. Truong, A.H.; Kim, M.; Nguyen, T.; Nguyen, N.; Quang Trung, N. Methane, nitrous oxide and ammonia emissions from livestock farming in the red river delta, Vietnam: An inventory and projection for 2000-2030. Sustainability 2018, 10, 3826. [CrossRef]

12. Baert, N.; Pellikaan, W.F.; Karonen, M.; Salminen, J.-P. A study of the structure-activity relationship of oligomeric ellagitannins on ruminal fermentation in vitro. J. Dairy Sci. 2016, 99, 8041-8052. [CrossRef] [PubMed]

13. Zucker, W.V. Tannins: Does structure determine function? An ecological perspective. Am. Nat. 1983, 121, 335-365. [CrossRef]

14. Chung, Y.H.; Mc Geough, E.J.; Acharya, S.; McAllister, T.A.; McGinn, S.M.; Harstad, O.M.; Beauchemin, K.A. Enteric methane emission, diet digestibility, and nitrogen excretion from beef heifers fed sainfoin or alfalfa. J. Anim. Sci. 2013, 91, 4861-4874. [CrossRef]

15. Huyen, N.T.; Desrues, O.; Alferink, S.J.J.; Zandstra, T.; Verstegen, M.W.A.; Hendriks, W.H.; Pellikaan, W.F. Inclusion of sainfoin (Onobrychis viciifolia) silage in dairy cow rations affects nutrient digestibility, nitrogen utilization, energy balance, and methane emissions. J. Dairy Sci. 2016, 99, 3566-3577. [CrossRef]

16. Guglielmelli, A.; Calabrò, S.; Primi, R.; Carone, F.; Cutrignelli, M.; Raffaella, T.; Piccolo, G.; Ronchi, B.; Danieli, P.P. In vitro fermentation patterns and methane production of sainfoin (Onobrychis viciifolia Scop.) hay with different condensed tannin contents. Grass Forage Sci. 2011, 66, 488-500. [CrossRef]

17. Grosse Brinkhaus, A.; Wyss, U.; Arrigo, Y.; Girard, M.; Bee, G.; Zeitz, J.O.; Kreuzer, M.; Dohme-Meier, F. In vitro ruminal fermentation characteristics and utilisable CP supply of sainfoin and birdsfoot trefoil silages and their mixtures with other legumes. Animal 2017, 11, 580-590. [CrossRef] [PubMed]

18. McMahon, L.R.; Majak, W.; McAllister, T.A.; Hall, J.W.; Jones, G.A.; Popp, J.D.; Cheng, K.J. Effect of sainfoin on in vitro digestion of fresh alfalfa and bloat in steers. Can. J. Anim. Sci. 1999, 79, 203-212. [CrossRef]

19. Wang, Y.; Berg, B.P.; Barbieri, L.R.; Veira, D.M.; McAllister, T.A. Comparison of alfalfa and mixed alfalfa-sainfoin pastures for grazing cattle: Effects on incidence of bloat, ruminal fermentation, and feed intake. Can. J. Anim. Sci. 2006, 86, 383-392. [CrossRef]

20. Aufrere, J.; Dudilieu, M.; Andueza, D.; Poncet, C.; Baumont, R. Mixing sainfoin and lucerne to improve the feed value of legumes fed to sheep by the effect of condensed tannins. Animal 2013, 7, 82-92. [CrossRef] [PubMed]

21. Theodoridou, K.; Aufrere, J.; Andueza, D.; Le Morvan, A.; Picard, F.; Pourrat, J.; Baumont, R. Effects of condensed tannins in wrapped silage bales of sainfoin (Onobrychis viciifolia) on in vivo and in situ digestion in sheep. Animal 2012, 6, 245-253. [CrossRef] [PubMed]

22. Malisch, C.S.; Lüscher, A.; Baert, N.; Engström, M.T.; Studer, B.; Fryganas, C.; Suter, D.; Mueller-Harvey, I.; Salminen, J.-P. Large variability of proanthocyanidin content and composition in sainfoin (Onobrychis viciifolia). J. Agric. Food Chem. 2015, 63, 10234-10242. [CrossRef]

23. Stringano, E.; Hayot Carbonero, C.; Smith, L.M.; Brown, R.H.; Mueller-Harvey, I. Proanthocyanidin diversity in the EU 'HealthyHay' sainfoin (Onobrychis viciifolia) germplasm collection. Phytochemistry 2012, 77, 197-208. [CrossRef]

24. Hatew, B.; Hayot Carbonero, C.; Stringano, E.; Sales, L.F.; Smith, L.M.J.; Mueller-Harvey, I.; Hendriks, W.H.; Pellikaan, W.F. Diversity of condensed tannin structures affects rumen in vitro methane production in sainfoin (Onobrychis viciifolia) accessions. Grass Forage Sci. 2015, 70, 474-490. [CrossRef]

25. Hatew, B.; Stringano, E.; Mueller-Harvey, I.; Hendriks, W.H.; Carbonero, C.H.; Smith, L.M.; Pellikaan, W.F. Impact of variation in structure of condensed tannins from sainfoin (Onobrychis viciifolia) on in vitro ruminal methane production and fermentation characteristics. J. Anim. Physiol. Anim. Nutr. 2016, 100, 348-360. [CrossRef] [PubMed]

26. Jayanegara, A.; Marquardt, S.; Wina, E.; Kreuzer, M.; Leiber, F. In vitro indications for favourable non-additive effects on ruminal methane mitigation between high-phenolic and high-quality forages. Br. J. Nutr. 2013, 109, 615-622. [CrossRef] [PubMed]

27. Malisch, C.; Salminen, J.-P.; Kölliker, R.; Engström, M.; Suter, D.; Studer, B.; Lüscher, A. Drought effects on proanthocyanidins in sainfoin (Onobrychis viciifolia Scop.) are dependent on the plant's ontogenetic stage. J. Agric. Food Chem. 2016, 64, 9307-9316. [CrossRef] [PubMed]

28. Selmar, D.; Kleinwaechter, M. stress enhances the synthesis of secondary plant products: The impact of stress-related overreduction on the accumulation of natural products. Plant. Cell Physiol. 2013, 54, 817-826. [CrossRef] [PubMed]

29. Zhang, L.H.; Shao, H.B.; Ye, G.F.; Lin, Y.M. Effects of fertilization and drought stress on tannin biosynthesis of Casuarina equisetifolia seedlings branchlets. Acta. Physiol. Plant. 2012, 34, 1639-1649. [CrossRef]

30. Top, S.M.; Preston, C.M.; Dukes, J.S.; Tharayil, N. Climate influences the content and chemical composition of foliar tannins in green and senesced tissues of Quercus rubra. Front. Plant. Sci. 2017, 8, 423. [CrossRef] [PubMed]

31. Haslam, E. Plant polyphenols (syn. vegetable tannins) and chemical defense-A reappraisal. J. Chem. Ecol. 1988, 14, 1789-1805. [CrossRef] [PubMed] 
32. Mueller-Harvey, I.; Bee, G.; Dohme-Meier, F.; Hoste, H.; Karonen, M.; Kölliker, R.; Luscher, A.; Nidekorn, V.; Pellikaan, W.F.; Salminen, J.-P.; et al. Benefits of condensed tannins in forage legumes fed to ruminants: Importance of structure, concentration and diet composition. Crop Sci. 2017, 59, 861-885. [CrossRef]

33. Salminen, J.-P.; Karonen, M. Chemical ecology of tannins and other phenolics: We need a change in approach. Funct. Ecol. 2011, 25, 325-338. [CrossRef]

34. Salminen, J.P.; Karonen, M.; Sinkkonen, J. Chemical ecology of tannins: Recent developments in tannin chemistry reveal new structures and structure-activity patterns. Chem. Eur. J. 2011, 17, 2806-2816. [CrossRef] [PubMed]

35. Sharma, P.; Jha, A.; Dubey, R.; Pessarakli, M. Reactive oxygen species, oxidative damage, and antioxidative defense mechanism in plants under stressful conditions. J. Bot. 2012, 2012, 217037. [CrossRef]

36. Chomel, M.; Guittonny-Larchevêque, M.; Fernandez, C.; Gallet, C.; DesRochers, A.; Paré, D.; Jackson, B.G.; Baldy, V. Plant secondary metabolites: A key driver of litter decomposition and soil nutrient cycling. J. Ecol. 2016, 104, 1527-1541. [CrossRef]

37. Adamczyk, B.; Karonen, M.; Adamczyk, S.; Engström, M.T.; Laakso, T.; Saranpää, P.; Kitunen, V.; Smolander, A.; Simon, J. Tannins can slow-down but also speed-up soil enzymatic activity in boreal forest. Soil Biol. Biochem. 2017, 107, 60-67. [CrossRef]

38. Adamczyk, B.; Simon, J.; Kitunen, V.; Adamczyk, S.; Smolander, A. Tannins and their complex interaction with different organic nitrogen compounds and enzymes: Old paradigms versus recent advances. Chem. Open 2017, 6, 610-614. [CrossRef] [PubMed]

39. Adamczyk, S.; Kitunen, V.; Lindroos, A.-J.; Adamczyk, B.; Smolander, A. Soil carbon and nitrogen cycling processes and composition of terpenes five years after clear-cutting a Norway spruce stand: Effects of logging residues. For. Ecol. Manag. 2016, 381, 318-326. [CrossRef]

40. Kagiya, N.; Reinsch, T.; Taube, F.; Salminen, J.-P.; Kluß, C.; Hasler, M.; Malisch, C.S. Turnover rates of roots vary considerably across temperate forage species. Soil Biol. Biochem. 2019, 139, 107614. [CrossRef]

41. Salami, S.A.; Valenti, B.; Bella, M.; O’Grady, M.N.; Luciano, G.; Kerry, J.P.; Jones, E.; Priolo, A.; Newbold, C.J. Characterisation of the ruminal fermentation and microbiome in lambs supplemented with hydrolysable and condensed tannins. FEMS Microbiol. Ecol. 2018, 94. [CrossRef]

42. Ekambaram, S.P.; Perumal, S.S.; Balakrishnan, A. Scope of hydrolysable tannins as possible antimicrobial agent. Phytother. Res. 2016, 30, 1035-1045. [CrossRef] [PubMed]

43. Koleckar, V.; Kubikova, K.; Rehakova, Z.; Kuca, K.; Jun, D.; Jahodar, L.; Opletal, L. Condensed and hydrolysable tannins as antioxidants influencing the health. Mini Rev. Med. Chem. 2008, 8, 436-447. [CrossRef]

44. Klongsiriwet, C.; Quijada, J.; Williams, A.R.; Mueller-Harvey, I.; Williamson, E.M.; Hoste, H. Synergistic inhibition of Haemonchus contortus exsheathment by flavonoid monomers and condensed tannins. Int. J. Parasitol. Drugs Drug Resist. 2015, 5, 127-134. [CrossRef] [PubMed]

45. Desrues, O.; Fryganas, C.; Ropiak, H.M.; Mueller-Harvey, I.; Enemark, H.L.; Thamsborg, S.M. Impact of chemical structure of flavanol monomers and condensed tannins on in vitro anthelmintic activity against bovine nematodes. Parasitology 2016, 143, 444-454. [CrossRef]

46. Williams, A.R.; Fryganas, C.; Ramsay, A.; Mueller-Harvey, I.; Thamsborg, S.M. Direct anthelmintic effects of condensed tannins from diverse plant sources against Ascaris Suum. PLoS ONE 2014, 9, e97053. [CrossRef] [PubMed]

47. Rasmussen, S.E.; Frederiksen, H.; Krogholm, K.S.; Poulsen, L. Dietary proanthocyanidins: Occurrence, dietary intake, bioavailability, and protection against cardiovascular disease. Mol. Nutr. Food Res. 2005, 49, 159-174. [CrossRef] [PubMed]

48. Zeller, W.E.; Ramsay, A.; Ropiak, H.M.; Fryganas, C.; Mueller-Harvey, I.; Brown, R.H.; Drake, C.; Grabber, J.H. 1H-13C HSQC NMR spectroscopy for estimating procyanidin/prodelphinidin and cis/trans-flavan-3-ol ratios of condensed tannin samples: Correlation with thiolysis. J. Agric. Food Chem. 2015, 63, 1967-1973. [CrossRef]

49. Naumann, H.D.; Tedeschi, L.O.; Zeller, W.E.; Huntley, N.F. The role of condensed tannins in ruminant animal production: Advances, limitations and future directions. Rev. Bras. Zootec. 2017, 46, 929-949. [CrossRef]

50. Barry, T.N.; McNabb, W.C. The implications of condensed tannins on the nutritive value of temperate forages fed to ruminants. Br. J. Nutr. 1999, 81, 263-272. [CrossRef]

51. Zeller, W.E.; Sullivan, M.L.; Mueller-Harvey, I.; Grabber, J.H.; Ramsay, A.; Drake, C.; Brown, R.H. Protein precipitation behavior of condensed tannins from Lotus pedunculatus and Trifolium repens with different mean degrees of polymerization. J. Agric. Food Chem. 2015, 63, 1160-1168. [CrossRef]

52. Kimura, H.; Ogawa, S.; Akihiro, T.; Yokota, K. Structural analysis of A-type or B-type highly polymeric proanthocyanidins by thiolytic degradation and the implication in their inhibitory effects on pancreatic lipase. J. Chromatogr. A 2011, 1218, 7704-7712. [CrossRef]

53. Girard, M.; Dohme-Meier, F.; Silacci, P.; Ampuero Kragten, S.; Kreuzer, M.; Bee, G. Forage legumes rich in condensed tannins may increase n-3 fatty acid levels and sensory quality of lamb meat. J. Sci. Food Agric. 2016, 96, 1923-1933. [CrossRef]

54. Tibe, O.; Meagher, L.P.; Fraser, K.; Harding, D.R.K. Condensed tannins and flavonoids from the forage legume sulla (Hedysarum coronarium). J. Agric. Food Chem. 2011, 59, 9402-9409. [CrossRef] [PubMed]

55. Aerts, R.J.; Barry, T.N.; McNabb, W.C. Polyphenols and agriculture: Beneficial effects of proanthocyanidins in forages. Agric. Ecosyst. Environ. 1999, 75, 1-12. [CrossRef]

56. Kim, J.; Pälijärvi, M.; Karonen, M.; Salminen, J.-P. Distribution of enzymatic and alkaline oxidative activities of phenolic compounds in plants. Phytochemistry 2020, 179, 112501. [CrossRef] 
57. Barbehenn, R.V.; Jones, C.P.; Hagerman, A.E.; Karonen, M.; Salminen, J.P. Ellagitannins have greater oxidative activities than condensed tannins and galloyl glucoses at high pH: Potential impact on caterpillars. J. Chem. Ecol. 2006, 32, 2253-2267. [CrossRef] [PubMed]

58. Barbehenn, R.V.; Peter Constabel, C. Tannins in plant-herbivore interactions. Phytochemistry 2011, 72, 1551-1565. [CrossRef] [PubMed]

59. Mueller-Harvey, I. Unravelling the conundrum of tannins in animal nutrition and health. J. Sci. Food Agric. 2006, 86, 2010-2037. [CrossRef]

60. Desrues, O.; Mueller-Harvey, I.; Pellikaan, W.F.; Enemark, H.L.; Thamsborg, S.M. Condensed tannins in the gastrointestinal tract of cattle after sainfoin (Onobrychis viciifolia) intake and their possible relationship with anthelmintic effects. J. Agric. Food Chem. 2017, 65, 1420-1427. [CrossRef]

61. Zhang, L.L.; Lin, Y.M. HPLC, NMR and MALDI-TOF MS analysis of condensed tannins from Lithocarpus glaber leaves with potent free radical scavenging activity. Molecules 2008, 13, 2986-2997. [CrossRef] [PubMed]

62. Aboagye, I.A.; Beauchemin, K.A. Potential of molecular weight and structure of tannins to reduce methane emissions from ruminants: A review. Animals 2019, 9, 856. [CrossRef] [PubMed]

63. Adamczyk, B.; Salminen, J.-P.; Smolander, A.; Kitunen, V. Precipitation of proteins by tannins: Effects of concentration, protein/tannin ratio and pH. Int. J. Food Sci. Technol. 2011, 47, 875-878. [CrossRef]

64. Zeller, W.E. Activity, purification, and analysis of condensed tannins: Current state of affairs and future endeavors. Crop Sci. 2019, 59, 886-904. [CrossRef]

65. Prigent, S.V.E.; Voragen, A.G.J.; van Koningsveld, G.A.; Baron, A.; Renard, C.M.G.C.; Gruppen, H. Interactions between globular proteins and procyanidins of different degrees of polymerization. J. Dairy Sci. 2009, 92, 5843-5853. [CrossRef] [PubMed]

66. McMahon, L.R.; McAllister, T.A.; Berg, B.P.; Majak, W.; Acharya, S.N.; Popp, J.D.; Coulman, B.E.; Wang, Y.; Cheng, K.J. A review of the effects of forage condensed tannins on ruminal fermentation and bloat in grazing cattle. Can. J. Plant. Sci. 2000, 80, 469-485. [CrossRef]

67. Engström, M.T.; Sun, X.; Suber, M.P.; Li, M.; Salminen, J.-P.; Hagerman, A.E. The oxidative activity of ellagitannins dictates their tendency to form highly stabilized complexes with bovine serum albumin at increased pH. J. Agric. Food Chem. 2016, 64, 8994-9003. [CrossRef] [PubMed]

68. Hagerman, A.E. Fifty years of polyphenol-protein complexes. In Recent Advances in Polyphenol Research; Cheynier, V., SarniManchado, P., Quideau, S., Eds.; Wiley: Hoboken, NJ, USA, 2012; Volume 3, pp. 71-97.

69. Leppä, M.M.; Laitila, J.E.; Salminen, J.-P. Distribution of protein precipitation capacity within variable proanthocyanidin fingerprints. Molecules 2020, 25, 5002. [CrossRef]

70. Schofield, P.; Mbugua, D.M.; Pell, A.N. Analysis of condensed tannins: A review. Anim. Feed Sci. Technol. 2001, 91, 21-40. [CrossRef]

71. Ropiak, H.M.; Desrues, O.; Williams, A.R.; Ramsay, A.; Mueller-Harvey, I.; Thamsborg, S.M. Structure-activity relationship of condensed tannins and synergism with trans-cinnamaldehyde against Caenorhabditis elegans. J. Agric. Food Chem. 2016, 64, 8795-8805. [CrossRef] [PubMed]

72. Naumann, H.D.; Armstrong, S.A.; Lambert, B.D.; Muir, J.P.; Tedeschi, L.O.; Kothmann, M.M. Effect of molecular weight and concentration of legume condensed tannins on in vitro larval migration inhibition of Haemonchus contortus. Vet. Parasitol. 2014, 199, 93-98. [CrossRef]

73. Naumann, H.D.; Hagerman, A.E.; Lambert, B.D.; M-uir, J.P.; Tedeschi, L.O.; Kothmann, M.M. Molecular weight and proteinprecipitating ability of condensed tannins from warm-season perennial legumes. J. Plant Interact. 2014, 9, 212-219. [CrossRef]

74. McAllister, T.A.; Martinez, T.; Bae, H.D.; Muir, A.D.; Yanke, L.J.; Jones, G.A. Characterization of condensed tannins purified from legume forages: Chromophore production, protein precipitation, and inhibitory effects on cellulose digestion. J. Chem. Ecol. 2005, 31, 2049-2068. [CrossRef] [PubMed]

75. O'Donovan, L.; Brooker, J.D. Effect of hydrolysable and condensed tannins on growth, morphology and metabolism of Streptococcus gallolyticus (S. caprinus) and Streptococcus bovis. Microbiology 2001, 147, 1025-1033. [CrossRef]

76. Stienezen, M.; Waghorn, G.C.; Douglas, G.B. Digestibility and effects of condensed tannins on digestion of sulla Hedysarum coronarium) when fed to sheep. N. Zeal. J. Agric. Res. 1996, 39, 215-221. [CrossRef]

77. Häring, D.A.; Scharenberg, A.; Heckendorn, F.; Dohme, F.; Lüscher, A.; Maurer, V.; Suter, D.; Hertzberg, H. Tanniferous forage plants: Agronomic performance, palatability and efficacy against parasitic nematodes in sheep. Renew. Agric. Food Syst. 2008, 23, 19-29. [CrossRef]

78. Grosse Brinkhaus, A.; Bee, G.; Silacci, P.; Kreuzer, M.; Dohme-Meier, F. Effect of exchanging Onobrychis viciifolia and Lotus corniculatus for Medicago sativa on ruminal fermentation and nitrogen turnover in dairy cows. J. Dairy Sci. 2016, 99, $4384-4397$. [CrossRef]

79. Johnson, K.A.; Johnson, D.E. Methane emissions from cattle. J. Anim. Sci. 1995, 73, 2483-2492. [CrossRef]

80. Morgavi, D.P.; Forano, E.; Martin, C.; Newbold, C.J. Microbial ecosystem and methanogenesis in ruminants. Animal 2010, 4, 1024-1036. [CrossRef]

81. Peng, K.; Jin, L.; Niu, Y.D.; Huang, Q.; McAllister, T.A.; Yang, H.E.; Denise, H.; Xu, Z.; Acharya, S.; Wang, S.; et al. Condensed tannins affect bacterial and fungal microbiomes and mycotoxin production during ensiling and upon aerobic exposure. Appl. Environ. Microbiol. 2018, 84, e02274-17. [CrossRef] [PubMed] 
82. Waghorn, G.C.; Ulyatt, M.J.; John, A.; Fisher, M.T. The effect of condensed tannins on the site of digestion of amino acids and other nutrients in sheep fed on Lotus corniculatus L. Br. J. Nutr. 1987, 57, 115-126. [CrossRef]

83. Athanasiadou, S.; Kyriazakis, I.; Jackson, F.; Coop, R.L. Consequences of long-term feeding with condensed tannins on sheep parasitised with Trichostrongylus colubriformis. Int. J. Parasitol. 2000, 30, 1025-1033. [CrossRef]

84. Makkar, H. Chemical, protein precipitation and bioassays for tannins, tannin levels and activity in unconventional feeds, and effects and fate of tannins. In Quantification of Tannins in Tree and Shrub Foliage: A Laboratory Manual; Makkar, H.P.S., Ed.; Springer: Dordrecht, The Netherlands, 2003; pp. 1-42.

85. Gunun, P.; Wanapat, M.; Gunun, N.; Cherdthong, A.; Sirilaophaisan, S.; Kaewwongsa, W. Effects of condensed tannins in Mao (Antidesma thwaitesianum Muell. Arg.) seed meal on rumen fermentation characteristics and nitrogen utilization in Goats. Asian-Australas. J. Anim. Sci. 2016, 29, 1111-1119. [CrossRef] [PubMed]

86. Hassanat, F.; Benchaar, C. Assessment of the effect of condensed (acacia and quebracho) and hydrolysable (chestnut and valonea) tannins on rumen fermentation and methane production in vitro. J. Sci. Food Agric. 2013, 93, 332-339. [CrossRef] [PubMed]

87. Sordi, A.; Dieckow, J.; Bayer, C.; Alburquerque, M.A.; Piva, J.T.; Zanatta, J.A.; Tomazi, M.; da Rosa, C.M.; de Moraes, A. Nitrous oxide emission factors for urine and dung patches in a subtropical Brazilian pastureland. Agric. Ecosyst. Environ. 2014, 190, 94-103. [CrossRef]

88. Azuhnwi, B.N.; Hertzberg, H.; Arrigo, Y.; Gutzwiller, A.; Hess, H.D.; Mueller-Harvey, I.; Torgerson, P.R.; Kreuzer, M.; DohmeMeier, F. Investigation of sainfoin (Onobrychis viciifolia) cultivar differences on nitrogen balance and fecal egg count in artificially infected lambs. J. Anim. Sci. 2013, 91, 2343-2354. [CrossRef]

89. Min, B.R.; Attwood, G.T.; Reilly, K.; Sun, W.; Peters, J.S.; Barry, T.N.; McNabb, W.C. Lotus corniculatus condensed tannins decrease in vivo populations of proteolytic bacteria and affect nitrogen metabolism in the rumen of sheep. Can. J. Microbiol. 2002, 48, 911-921. [CrossRef] [PubMed]

90. Naumann, H.; Sepela, R.; Rezaire, A.; Masih, S.E.; Zeller, W.E.; Reinhardt, L.A.; Robe, J.T.; Sullivan, M.L.; Hagerman, A.E. Relationships between structures of condensed tannins from texas legumes and methane production during in vitro rumen digestion. Molecules 2018, 23, 2123. [CrossRef] [PubMed]

91. Aerts, R.J.; McNabb, W.C.; Molan, A.; Brand, A.; Barry, T.N.; Peters, J.S. Condensed tannins from Lotus corniculatus and Lotus pedunculatus exert different effects on the in vitro rumen degradation of ribulose-1,5-bisphosphate carboxylase/oxygenase (Rubisco) protein. J. Sci. Food Agric. 1999, 79, 79-85. [CrossRef]

92. Cieslak, A.; Szumacher-Strabel, M.; Stochmal, A.; Oleszek, W. Plant components with specific activities against rumen methanogens. Animal 2013, 7, 253-265. [CrossRef] [PubMed]

93. Hristov, A.N.; Oh, J.; Firkins, J.L.; Dijkstra, J.; Kebreab, E.; Waghorn, G.; Makkar, H.P.S.; Adesogan, A.T.; Yang, W.; Lee, C.; et al. Special topics-Mitigation of methane and nitrous oxide emissions from animal operations: I. A review of enteric methane mitigation options. J. Anim. Sci. 2013, 91, 5045-5069. [CrossRef] [PubMed]

94. Pedreira, M.d.S.; Oliveira, S.G.d.; Primavesi, O.; Lima, M.A.d.; Frighetto, R.T.S.; Berchielli, T.T. Methane emissions and estimates of ruminal fermentation parameters in beef cattle fed different dietary concentrate levels. Rev. Bras. Zootec. 2013, 42, 592-598. [CrossRef]

95. Huyen, N.T.; Fryganas, C.; Uittenbogaard, G.; Mueller-Harvey, I.; Verstegen, M.W.A.; Hendriks, W.H.; Pellikaan, W.F. Structural features of condensed tannins affect in vitro ruminal methane production and fermentation characteristics. J. Agric. Sci. 2016, 154, 1474-1487. [CrossRef]

96. Hristov, A.N.; Oh, J.; Giallongo, F.; Frederick, T.W.; Harper, M.T.; Weeks, H.L.; Branco, A.F.; Moate, P.J.; Deighton, M.H.; Williams, S.R.O.; et al. An inhibitor persistently decreased enteric methane emission from dairy cows with no negative effect on milk production. Proc. Natl. Acad. Sci. USA 2015, 112, 10663-10668. [CrossRef] [PubMed]

97. Saminathan, M.; Sieo, C.C.; Gan, H.M.; Abdullah, N.; Wong, C.M.V.L.; Ho, Y.W. Effects of condensed tannin fractions of different molecular weights on population and diversity of bovine rumen methanogenic archaea in vitro, as determined by high-throughput sequencing. Anim. Feed Sci. Technol. 2016, 216, 146-160. [CrossRef]

98. Belanche, A.; de la Fuente, G.; Newbold, C.J. Study of methanogen communities associated with different rumen protozoal populations. FEMS Microbiol. Ecol. 2014, 90, 663-677. [CrossRef]

99. Beauchemin, K.; McAllister, T.; McGinn, S. Dietary mitigation of enteric methane from cattle. CAB Rev. 2009, 4, 1-18. [CrossRef]

100. Tavendale, M.H.; Meagher, L.P.; Pacheco, D.; Walker, N.; Attwood, G.T.; Sivakumaran, S. Methane production from in vitro rumen incubations with Lotus pedunculatus and Medicago sativa, and effects of extractable condensed tannin fractions on methanogenesis. Anim. Feed Sci. Technol. 2005, 123, 403-419. [CrossRef]

101. Jayanegara, A.; Leiber, F.; Kreuzer, M. Meta-analysis of the relationship between dietary tannin level and methane formation in ruminants from in vivo and in vitro experiments. J. Anim. Physiol. Anim. Nutr. 2012, 96, 365-375. [CrossRef] [PubMed]

102. Van Gastelen, S.; Dijkstra, J.; Bannink, A. Are dietary strategies to mitigate enteric methane emission equally effective across dairy cattle, beef cattle, and sheep? J. Dairy Sci. 2019, 102, 6109-6130. [CrossRef] [PubMed]

103. Min, B.R.; Solaiman, S.; Waldrip, H.M.; Parker, D.; Todd, R.W.; Brauer, D. Dietary mitigation of enteric methane emissions from ruminants: A review of plant tannin mitigation options. Anim. Nutr. 2020, 6, 231-236. [CrossRef]

104. Fagundes, G.M.; Benetel, G.; Santos, K.C.; Welter, K.C.; Melo, F.A.; Muir, J.P.; Bueno, I.C.S. Tannin-rich plants as natural manipulators of rumen fermentation in the livestock industry. Molecules 2020, 25, 2943. [CrossRef] 
105. Waghorn, G. Beneficial and detrimental effects of dietary condensed tannins for sustainable sheep and goat production-Progress and challenges. Anim. Feed Sci. Technol. 2008, 147, 116-139. [CrossRef]

106. Woodward, S.L.; Waghorn, G.C.; Laboyrie, P.G. Condensed tannins in birdsfoot trefoil (Lotus corniculatus) reduce methane emissions from dairy cows. Proc. N. Z. Soc. Anim. Prod. 2004, 64, 160-164.

107. Soltan, Y.A.; Morsy, A.S.; Lucas, R.C.; Abdalla, A.L. Potential of mimosine of Leucaena leucocephala for modulating ruminal nutrient degradability and methanogenesis. Anim. Feed Sci. Technol. 2017, 223, 30-41. [CrossRef]

108. Soltan, Y.A.; Morsy, A.S.; Sallam, S.M.A.; Lucas, R.C.; Louvandini, H.; Kreuzer, M.; Abdalla, A.L. Contribution of condensed tannins and mimosine to the methane mitigation caused by feeding Leucaena leucocephala. Arch. Anim. Nutr. 2013, 67, 169-184. [CrossRef] [PubMed]

109. Pineiro-Vazquez, A.T.; Canul-Solis, J.R.; Jimenez-Ferrer, G.O.; Alayon-Gamboa, J.A.; Chay-Canul, A.J.; Ayala-Burgos, A.J.; AguilarPerez, C.F.; Ku-Vera, J.C. Effect of condensed tannins from Leucaena leucocephala on rumen fermentation, methane production and population of rumen protozoa in heifers fed low-quality forage. Asian-Australas. J. Anim. Sci. 2018, 31, 1738-1746. [CrossRef] [PubMed]

110. Pathak, A.K.; Dutta, N.; Pattanaik, A.K.; Chaturvedi, V.B.; Sharma, K. Effect of condensed tannins from Ficus infectoria and Psidium guajava leaf meal mixture on nutrient metabolism, methane emission and performance of lambs. Asian-Australas. J. Anim. Sci. 2017, 30, 1702-1710. [CrossRef] [PubMed]

111. Wang, S.; Terranova, M.; Kreuzer, M.; Marquardt, S.; Eggerschwiler, L.; Schwarm, A. Supplementation of pelleted hazel (Corylus avellana) leaves decreases methane and urinary nitrogen emissions by sheep at unchanged forage intake. Sci. Rep. 2018, 8, 5427. [CrossRef]

112. Theodoridou, K.; Aufrère, J.; Andueza, D.; Le Morvan, A.; Picard, F.; Stringano, E.; Pourrat, J.; Mueller-Harvey, I.; Baumont, R. Effect of plant development during first and second growth cycle on chemical composition, condensed tannins and nutritive value of three sainfoin (Onobrychis viciifolia) varieties and lucerne. Grass Forage Sci. 2011, 66, 402-414. [CrossRef]

113. Diaz Carrasco, J.; Cabral, C.; Redondo, L.; Daniela Pin Viso, N.; Colombatto, D.; Diana Farber, M.; Fernandez Miyakawa, M. Impact of chestnut and quebracho tannins on rumen microbiota of bovines. Biomed. Res. Int. 2017, 2017, 9610810. [CrossRef] [PubMed]

114. Phesatcha, K.; Wanapat, M. Tropical legume supplementation influences microbial protein synthesis and rumen ecology. J. Anim. Physiol. Anim. Nutr. 2017, 101, 552-562. [CrossRef]

115. Tan, H.Y.; Sieo, C.C.; Abdullah, N.; Liang, J.B.; Huang, X.D.; Ho, Y.W. Effects of condensed tannins from Leucaena on methane production, rumen fermentation and populations of methanogens and protozoa in vitro. Anim. Feed Sci. Technol. 2011, 169, 185-193. [CrossRef]

116. Saminathan, M.; Sieo, C.C.; Gan, H.M.; Ravi, S.; Venkatachalam, K.; Abdullah, N.; Wong, C.M.V.L.; Ho, Y.W. Modulatory effects of condensed tannin fractions of different molecular weights from a Leucaena leucocephala hybrid on the bovine rumen bacterial community in vitro. J. Sci. Food Agric. 2016, 96, 4565-4574. [CrossRef]

117. Naumann, H.D.; Tedeschi, L.O.; Muir, J.P.; Lambert, B.D.; Kothmann, M.M. Effect of molecular weight of condensed tannins from warm-season perennial legumes on ruminal methane production in vitro. Biochem. Syst. Ecol. 2013, 50, 154-162. [CrossRef]

118. Williams, C.M.; Eun, J.S.; MacAdam, J.W.; Young, A.J.; Fellner, V.; Min, B.R. Effects of forage legumes containing condensed tannins on methane and ammonia production in continuous cultures of mixed ruminal microorganisms. Anim. Feed Sci. Technol. 2011, 166, 364-372. [CrossRef]

119. Woodward, S.L.; Waghorn, G.C.; Lassey, K. Early indications that feeding Lotus will reduce methane emissions from ruminants. Proc. N. Z. Soc. Anim. Prod. 2001, 61, 23-26.

120. Woodward, S.; Waghorn, G.; Lassey, K.; Laboyrie, P. Does feeding sulla (Hedysarum coronarium) reduce methane emissions from dairy cows? Proc. N. Z. Soc. Anim. Prod. 2002, 62, 227-230.

121. Salminen, J.-P. Effects of sample drying and storage, and choice of extraction solvent and analysis method on the yield of birch leaf hydrolyzable tannins. J. Chem. Ecol. 2003, 29, 1289-1305. [CrossRef] [PubMed]

122. Neilson, A.P.; O'Keefe, S.F.; Bolling, B.W. High-molecular-weight proanthocyanidins in foods: Overcoming analytical challenges in pursuit of novel dietary bioactive components. Annu. Rev. Food Sci. Technol. 2016, 7, 43-64. [CrossRef] [PubMed]

123. Lees, G.L. Condensed tannins in some forage legumes: Their role in the prevention of ruminant pasture bloat. In Plant Polyphenols: Synthesis, Properties, Significance, 1992/01/01 ed.; Hemingway, R.W., Laks, P.E., Eds.; Springer: Boston, MA, USA, 1992; pp. 915-934.

124. Häring, D.A.; Suter, D.; Amrhein, N.; Lüscher, A. Biomass allocation is an important determinant of the tannin concentration in growing plants. Ann. Bot. 2007, 99, 111-120. [CrossRef] [PubMed]

125. Frutos, P.; Hervás, G.; Giráldez, F.; Mantecón, A. Review. Tannins and ruminant nutrition. Span. J. Agric. Res. 2004, 2, 191-202. [CrossRef]

126. Hummer, W.; Schreier, P. Analysis of proanthocyanidins. Mol. Nutr. Food Res. 2008, 52, 1381-1398. [CrossRef] [PubMed]

127. Peng, K.; Huang, Q.; Xu, Z.; McAllister, T.A.; Acharya, S.; Mueller-Harvey, I.; Drake, C.; Cao, J.; Huang, Y.; Sun, Y.; et al. Characterization of condensed tannins from purple prairie clover (Dalea purpurea Vent.) conserved as either freeze-dried forage, sun-cured hay or silage. Molecules 2018, 23, 586. [CrossRef] [PubMed]

128. Sze-Tao, K.W.C.; Schrimpf, J.E.; Teuber, S.S.; Roux, K.H.; Sathe, S.K. Effects of processing and storage on walnut (Juglans regia L) tannins. J. Sci. Food Agric. 2001, 81, 1215-1222. [CrossRef] 
129. Kardel, M.; Taube, F.; Schulz, H.; Schütze, W.; Gierus, M. Different approaches to evaluate tannin content and structure of selected plant extracts-Review and new aspects. J. Appl. Bot. Food Qual. 2013, 86, 154-166. [CrossRef]

130. Chavan, U.; Shahidi, F.; Naczk, M. Extraction of condensed tannins from beach pea (Lathyrus maritimus L.) as affected by different solvents. Food Chem. 2001, 75, 509-512. [CrossRef]

131. Hagerman, A.E. Extraction of tannin from fresh and preserved leaves. J. Chem. Ecol. 1988, 14, 453-461. [CrossRef]

132. Aspé, E.; Fernández, K. The effect of different extraction techniques on extraction yield, total phenolic, and anti-radical capacity of extracts from Pinus radiata Bark. Ind. Crops Prod. 2011, 34, 838-844. [CrossRef]

133. Chupin, L.; Maunu, S.; Reynaud, S.; Pizzi, A.P.; Charrier, B.; Charrier-El Bouhtoury, F. Microwave assisted extraction of maritime pine (Pinus pinaster) bark: Impact of particle size and characterization. Ind. Crops Prod. 2015, 65, 142-149. [CrossRef]

134. Cork, S.J.; Krockenberger, A.K. Methods and pitfalls of extracting condensed tannins and other phenolics from plants: Insights from investigations on Eucalyptus leaves. J. Chem. Ecol. 1991, 17, 123-134. [CrossRef] [PubMed]

135. Grabber, J.H.; Zeller, W.E.; Mueller-Harvey, I. Acetone enhances the direct analysis of procyanidin- and prodelphinidin-based condensed tannins in Lotus species by the butanol-HCl-iron assay. J. Agric. Food Chem. 2013, 61, 2669-2678. [CrossRef]

136. Hixson, J.L.; Bindon, K.A.; Smith, P.A. Evaluation of direct phloroglucinolysis and colorimetric depolymerization assays and their applicability for determining condensed tannins in grape marc. J. Agric. Food Chem. 2015, 63, 9954-9962. [CrossRef] [PubMed]

137. Rubanza, C.D.K.; Shem, M.N.; Otsyina, R.; Bakengesa, S.S.; Ichinohe, T.; Fujihara, T. Polyphenolics and tannins effect on in vitro digestibility of selected Acacia species leaves. Anim. Feed Sci. Technol. 2005, 119, 129-142. [CrossRef]

138. Rira, M.; Morgavi, D.P.; Genestoux, L.; Djibiri, S.; Sekhri, I.; Doreau, M. Methanogenic potential of tropical feeds rich in hydrolyzable tannins. J. Anim. Sci. 2019, 97, 2700-2710. [CrossRef]

139. Pal, K.; Patra, A.; Sahoo, A.; Kumawat, P. Evaluation of several tropical tree leaves for methane production potential, degradability and rumen fermentation in vitro. Livest. Sci. 2015, 180, 98-105. [CrossRef]

140. Muir, J.P.; Terrill, T.H.; Mosjidis, J.A.; Luginbuhl, J.-M.; Miller, J.E.; Burke, J.M.; Coleman, S.W. Harvest regimen changes sericea lespedeza condensed tannin, fiber and protein concentrations. Grassl. Sci. 2018, 64, 137-144. [CrossRef]

141. Guimarães-Beelen, P.; Berchielli, T.; Beelen, R.; Filho, J.; Oliveira, S. Characterization of condensed tannins from native legumes of the Brazilian Northeastern semi-arid. Sci. Agric. 2006, 63, 522-528. [CrossRef]

142. Piluzza, G.; Sulas, L.; Bullitta, S. Tannins in forage plants and their role in animal husbandry and environmental sustainability: A review. Grass Forage Sci. 2014, 69, 32-48. [CrossRef]

143. Tibe, O.; Sutherland, I.A.; Lesperance, L.; Harding, D.R. The effect of purified condensed tannins of forage plants from Botswana on the free-living stages of gastrointestinal nematode parasites of livestock. Vet. Parasitol. 2013, 197, 160-167. [CrossRef]

144. Rufino-Moya, P.J.; Blanco, M.; Bertolin, J.R.; Joy, M. Methane production of fresh sainfoin, with or without PEG, and fresh alfalfa at different stages of maturity is similar but the fermentation end products vary. Animals 2019, 9, 197. [CrossRef] [PubMed]

145. Grabber, J.; Coblentz, W.; Riday, H.; Griggs, T.; Min, D.-H.; MacAdam, J.; Cassida, K. Protein and dry-matter degradability of european- and mediterranean-derived birdsfoot trefoil cultivars grown in the colder continental USA. Crop. Sci. 2015, 55, 1356. [CrossRef]

146. Grabber, J.H.; Riday, H.; Cassida, K.A.; Griggs, T.C.; Min, D.H.; MacAdam, J.W. Yield, morphological characteristics, and chemical composition of european-and mediterranean-derived birdsfoot trefoil cultivars grown in the colder continental United States. Crop. Sci. 2014, 54, 1893-1901. [CrossRef]

147. Kelman, W.; Tanner, G. Foliar Condensed Tannin Levels in Lotus Species Growing on Limed and Unlimed Soils in South-Eastern Australia. Proc. N. Z. Grassl. Assoc. 1990, 52, 51-54.

148. Wang, Y.; Waghorn, G.C.; Barry, T.N.; Shelton, I.D. The effect of condensed tannins in Lotus corniculatus on plasma metabolism of methionine, cystine and inorganic sulphate by sheep. Br. J. Nutr. 1994, 72, 923-935. [CrossRef] [PubMed]

149. Barry, T.N. The role of condensed tannins in the nutritional value of Lotus pedunculatus for sheep. Rates of body and wool growth. Br. J. Nutr. 1985, 54, 211-217. [CrossRef]

150. Diez, M.T.; Garcia del Moral, P.; Resines, J.A.; Arin, M.J. Determination of phenolic compounds derived from hydrolysable tannins in biological matrices by RP-HPLC. J. Sep. Sci. 2008, 31, 2797-2803. [CrossRef]

151. Tuominen, A.; Karonen, M. Variability between organs of proanthocyanidins in Geranium sylvaticum analyzed by off-line 2-dimensional HPLC-MS. Phytochemistry 2018, 150, 106-117. [CrossRef] [PubMed]

152. Kelm, M.A.; Hammerstone, J.F.; Schmitz, H.H. Identification and quantitation of flavanols and proanthocyanidins in foods: How good are the datas? Clin. Dev. Immunol. 2005, 12, 35-41. [CrossRef] [PubMed]

153. Moilanen, J.; Sinkkonen, J.; Salminen, J.-P. Characterization of bioactive plant ellagitannins by chromatographic, spectroscopic and mass spectrometric methods. Chemoecology 2013, 23, 165-179. [CrossRef]

154. Yanagida, A.; Shoji, T.; Shibusawa, Y. Separation of proanthocyanidins by degree of polymerization by means of size-exclusion chromatography and related techniques. J. Biochem. Biophy. Meth. 2003, 56, 311-322. [CrossRef]

155. Karonen, M.; Ossipov, V.; Sinkkonen, J.; Loponen, J.; Haukioja, E.; Pihlaja, K. Quantitative analysis of polymeric proanthocyanidins in birch leaves with normal-phase HPLC. Phytochem Anal. 2006, 17, 149-156. [CrossRef] [PubMed]

156. Kelm, M.A.; Johnson, J.C.; Robbins, R.J.; Hammerstone, J.F.; Schmitz, H.H. High-performance liquid chromatography separation and purification of cacao (Theobroma cacao L.) procyanidins according to degree of polymerization using a diol stationary phase. $J$. Agric. Food Chem. 2006, 54, 1571-1576. [CrossRef] [PubMed] 
157. Mouls, L.; Mazauric, J.P.; Sommerer, N.; Fulcrand, H.; Mazerolles, G. Comprehensive study of condensed tannins by ESI mass spectrometry: Average degree of polymerisation and polymer distribution determination from mass spectra. Anal. Bioanal. Chem. 2011, 400, 613-623. [CrossRef]

158. Kalili, K.M.; Vestner, J.; Stander, M.A.; de Villiers, A. Toward unraveling grape tannin composition: Application of online hydrophilic interaction chromatography $\times$ reversed-phase liquid chromatography-time-of-flight mass spectrometry for grape seed analysis. Anal. Chem. 2013, 85, 9107-9115. [CrossRef] [PubMed]

159. Salminen, J.-P. Two-dimensional tannin fingerprints by liquid chromatography tandem mass spectrometry offer a new dimension to plant tannin analyses and help to visualize the tannin diversity in plants. J. Agric. Food Chem. 2018, 66, 9162-9171. [CrossRef] [PubMed]

160. Engström, M.T.; Pälijärvi, M.; Fryganas, C.; Grabber, J.H.; Mueller-Harvey, I.; Salminen, J.-P. Rapid qualitative and quantitative analyses of proanthocyanidin oligomers and polymers by UPLC-MS/MS. J. Agric. Food Chem. 2014, 62, 3390-3399. [CrossRef]

161. Saminathan, M.; Sieo, C.C.; Abdullah, N.; Wong, C.M.V.L.; Ho, Y.W. Effects of condensed tannin fractions of different molecular weights from a Leucaena leucocephala hybrid on in vitro methane production and rumen fermentation. J. Sci. Food Agric. 2015, 95, 2742-2749. [CrossRef] [PubMed]

162. MacAdam, J.W.; Villalba, J.J. Beneficial effects of temperate forage legumes that contain condensed tannins. Agriculture 2015, 5, 475-491. [CrossRef]

163. Waghorn, G.C.; Woodward, S.L.; Tavendale, M.; Clark, D.A. Inconsistencies in rumen methane production-Effects of forage composition and animal genotype. Int. Congr. Ser. 2006, 1293, 115-118. [CrossRef]

164. Huang, X.; Liang, J.; Tan, H.; Yahya, R.; Bodee, K.; Ho, Y. Molecular weight and protein binding affinity of Leucaena condensed tannins and their effects on in vitro fermentation parameters. Anim. Feed Sci. Technol. 2010, 159, 81-87. [CrossRef]

165. Paengkoum, P.; Phonmun, T.; Liang, J.B.; Huang, X.D.; Tan, H.Y.; Jahromi, M.F. Molecular weight, protein binding affinity and methane mitigation of condensed tannins from mangosteen-peel (Garcinia mangostana L). Asian-Australas. J. Anim. Sci. 2015, 28, 1442-1448. [CrossRef] [PubMed]

166. Huang, X.D.; Liang, J.B.; Tan, H.Y.; Yahya, R.; Ho, Y.W. Effects of Leucaena condensed tannins of differing molecular weights on in vitro $\mathrm{CH}_{4}$ production. Anim. Feed Sci. Technol. 2011, 166, 373-376. [CrossRef]

167. Hagerman, A.E.; Butler, L.G. Protein precipitation method for the quantitative determination of tannins. J. Agric. Food Chem. 1978, 26, 809-812. [CrossRef]

168. Makkar, H.P.; Dawra, R.K.; Singh, B. Protein precipitation assay for quantitation of tannins: Determination of protein in tannin-protein complex. Anal. Biochem. 1987, 166, 435-439. [CrossRef]

169. Ropiak, H.M.; Lachmann, P.; Ramsay, A.; Green, R.J.; Mueller-Harvey, I. Identification of structural features of condensed tannins that affect protein aggregation. PLoS ONE 2017, 12, e0170768. [CrossRef]

170. Tan, H.Y.; Sieo, C.C.; Lee, C.M.; Abdullah, N.; Liang, J.B.; Ho, Y.W. Diversity of bovine rumen methanogens in vitro in the presence of condensed tannins, as determined by sequence analysis of $16 \mathrm{~S}$ rRNA gene library. Int. J. Microbiol. 2011, 49, 492-498. [CrossRef]

171. Denman, S.E.; Martinez Fernandez, G.; Shinkai, T.; Mitsumori, M.; McSweeney, C.S. Metagenomic analysis of the rumen microbial community following inhibition of methane formation by a halogenated methane analog. Front. Microbiol. 2015, 6, 1087. [CrossRef] [PubMed]

172. Fay, M.F.; Dale, P.J. Condensed tannins in Trifolium species and their significance for taxonomy and plant breeding. Genet. Resour. Crop. Evol. 1993, 40, 7-13. [CrossRef]

173. Roldan, M.B.; Cousins, G.; Fraser, K.; Hancock, K.R.; Collette, V.; Demmer, J.; Woodfield, D.R.; Caradus, J.R.; Jones, C.; Voisey, C.R. Elevation of condensed tannins in the leaves of Ta-MYB14-1 white clover (Trifolium repens L.) outcrossed with high anthocyanin lines. J. Agric. Food Chem. 2020, 68, 2927-2939. [CrossRef] [PubMed]

174. Real, D.; Sandral, G.; Rebuffo, M.; Hughes, S.; Kelman, W.; Mieres, J.; Dods, K.; Crossa, J. Breeding of an early-flowering and drought-tolerant Lotus corniculatus L. variety for the high-rainfall zone of southern Australia. Crop. Pasture Sci. 2012, 63, 848-857. [CrossRef] 